\title{
Modelling size and liquidity in North African industrial sectors
}

\author{
Bruce Hearn* \\ University of Leicester
}

\begin{abstract}
This paper studies size and liquidity effects across North African industry portfolios using an augmented CAPM model with both linear and time varying coefficients. Furthermore this analysis is extended by the use of both regional as well as separate market universes for Algeria, Egypt, Morocco and Egypt to account for considerable segmentation. The evidence suggests that size and liquidity effects are prevalent in Egypt and Tunisia while time varying liquidity profiles suggest Egypt and Morocco have been substantially affected by global financial downturn. Costs of equity are highest in Egypt, then Morocco and lowest in Tunisia and Algeria.
\end{abstract}

JEL classification: G11, G12, G15, O55

Keywords: Liquidity, CAPM, Kalman filter, Emerging Financial Markets, North Africa

* Corresponding author: School of Management, University of Leicester, Ken Edwards Building, Leicester. UK. LE1 7RH. Tel: 44(0)116 252 5141. Email: bruce.hearn@le.ac.uk 


\title{
Costs of Equity in North Africa's equity markets: an Industrial Sector Study
}

\begin{abstract}
This study estimates liquidity premiums using the recently developed Liu (2006) measure within a multifactor capital asset pricing model (CAPM) including size premiums and a time varying parameter model for the North African emerging markets of Algeria, Egypt, Morocco and Tunisia. The evidence suggests that size and liquidity effects are least significant in Morocco which is reflected in its low cost of equity while that in Egypt and Tunisia is significantly higher. Time varying profiles of liquidity betas provide evidence that Morocco and Egypt have been affected by the 2007/2008 global financial crisis while the Tunisian market is relatively unaffected.
\end{abstract}

\section{INTRODUCTION}

The application of standard asset pricing theory dictates that expected stock returns are related cross-sectionally to returns sensitivities to state variables that are themselves linked to investors overall welfare (Pastor and Stambaugh, 2003). Assets whose lowest returns accompany unfavourable shifts in that welfare must compensate investors for the loss of value while holding the asset. There is considerable recent evidence that liquidity is such a state variable (Liu (2006); Pastor and Stambaugh (2003); Martinez et al. (2005)) that must be accounted for in pricing models. However the presence of size effects is likely, especially within the smaller North African regional stock markets where the majority of listings arise either from occasional listings of major multinational enterprises (MNEs) and privatizations of state owned enterprises (SOEs) or from indigenous family-owned small and medium enterprises (SMEs). While small size firms are also likely to be highly illiquid there is likely to be a difference between the two effects due to strong liquidity preferences of investors. Consequently this empirical study investigates whether both size and liquidity effects are priced. As such I ask whether differences in cross sectional expected returns can be explained by fluctuations in aggregate market size and liquidity effects. Furthermore I extend this question in asking whether these size and liquidity effects vary over time.

North African financial markets are at the forefront of the Maghreb regional development policy due to their potential role as a source of sustainable finance supporting industrial development and economic growth (NEPAD website, 2009). However unlike in the rest of Africa development policy promoting full integration of financial markets has been pursued at a noticeably slower pace. As such there has been greater focus in the signing of memorandums of understanding (MoU) between exchanges both within the region and globally (CASE website, 2009) and the fostering of partnerships that promote commercial awareness and training as well as the sharing of technical knowledge and resources (El-Khatib, 2008). There is considerable international 
awareness of these markets both from their position in the Mediterranean basin in proximity to the European Union (EU) but also due to their inclusion in major international benchmark indices such as MSCI, Standard \& Poors and FTSE that has provided significant marketing exposure to global portfolio managers. Study of the region is also facilitated through all of the regions markets sharing the same common legal regime: that of French civil code ${ }^{1}$. This was established through a colonial relationship between France and Algeria, Morocco and Tunisia as well as through concerted influence on commercial legal codes in Egypt (La Porta et al (2008) and Kuran (2004)). However there are considerable differences in stock market awareness and culture between the countries as well as deeper reservations concerning public information disclosure of sensitive firm level information, a necessary feature of stock market regulation, in conservative family-dominated business environments (Kuran, 2005). This is likely to cause considerable segmentation between North Africa's financial markets which would question the implicit assumptions of integration held in CAPM methodology (Sharpe (1964); Lintner (1965)). Evidence from Hearn and Piesse (2009a) in their recent application of a size-liquidity augmented CAPM to African markets, subdivided into three universes including one focussed on North Africa, indicates the likelihood of significant segmentation across the Maghreb region. Consequently I am motivated in the application of this study to consider both an aggregate North African universe and cross section of stocks as well as three individual separate universes, for Morocco, Egypt and Tunisia respectively.

Liquidity as a concept is very hard to define largely because its representative characteristics transcend a number of transactional properties of markets including tightness, depth, resiliency (Lesmond, 2005) and information (O'Hara, 2003). The literature has traditionally been limited in only employing constructs capturing only one dimension of a multidimensional phenomenon. This typically centres on variants of the bid-ask spread (quoted or effective) in Amihud and Mendelsen (1986), the turnover measure of Datar et al. (1998), or measures relating to the price impact arising from traded volume such as Amihud (2002) and Pastor and Stambaugh (2003). However there is very little published research concerning measures capturing the trading speed dimension of liquidity, defined as the ability to transact large quantities quickly with little price impact (Liu (2006) and Pastor and Stambaugh (2003)). Furthermore there are serious concerns over existing one-dimensional constructs ability to fully capture liquidity risk and over their inaccurate estimation of the dimension they are intended to model. Serious concerns over the limitations of any one-dimensional measure to capture liquidity effectively have been cited by Pastor and Stambaugh (2003) and Amihud (2002) within the context of price-impact measures. Equally deficiencies in the application of the bid-ask spread construct have been highlighted in Lee

\footnotetext{
${ }^{1}$ There is also a much smaller stock exchange in Libya, established in March 2007, that adheres to legal regulation formed on Italian civil code. Listings have grown to seven local firms with 14 licensed brokers. Listings regulations follow those prevailing in Egypt and trading is undertaken 10-00am - 12-00midday Sunday to Thursday through an electronic continuous auction (Libyan stock exchange website, 2009). A very small exchange fully compliant with Islamic Shari'ya law also exists in Sudan (see Hearn et al, 2009)
} 
(1993) where evidence reveals that many large trades occur outside the bid-ask spread while many small trades are undertaken within it leading to potential bias. Further concerns over the application of one-dimensional measures focus on their being undefined in the presence of extremes of illiquidity as is a frequent occurrence in emerging markets (Lesmond, 2005). A more recent measure developed in Liu (2006) captures the trading speed dimension of liquidity which is defined as the standardized turnover-adjusted number of zero trading volumes over the past twelve months. It is multi-dimensional in nature, capturing effects relating to trading speed, trading quantity and trading cost, with an emphasis on trading speed, outlined as the continuity of trading and the potential delay in executing an order (Liu, 2006). An additional benefit from the use of this measure arises from its measurement robustness in the presence of significant illiquidity (Liu, 2006) although this has only been studied within the context of the developed market of the New York Stock Exchange. The considerable dispersion of extremes of liquidity both between and within MENA markets further justifies the use of the Liu (2006) measure.

The literature concerning the inclusion of liquidity as a priced state variable within a valuation framework is very recent. Pastor and Stambaugh (2003) find strong evidence from US stock data that market-wide liquidity is a priced state variable and that the liquidity premium should be positive. The study applied the innovations of a price impact measure of liquidity to sort stocks within a universe into decile portfolios with the market aggregate premium being formed in the difference between returns of the highest and lowest liquidity deciles. The explanatory power arising from inclusion of the liquidity factor were studied through the contrast of a four factor capital asset pricing model (CAPM) including market, size, book-to-market and the new liquidity factor against the Fama and French (1993) three factor model and the CAPM. Stocks with higher sensitivity to aggregate liquidity stocks compensate investors with higher expected returns. Evidence is also found that small stocks have greater sensitivities to liquidity innovations than large stocks. Pastor and Stambaugh (2003) note that intuitively it could be expected that small and illiquid stocks are those most affected by market aggregate drops in liquidity thereby precipitating investors to "flee" to assets with higher liquidity. However their findings also show that size and liquidity are not the sole determinants of liquidity betas. This finding is reinforced by the argument explaining why stocks with a high liquidity beta are not necessarily illiquid. Investor preferences when there are market aggregate falls in liquidity are also likely to focus on rival bonds markets. In order to increase portfolio holdings in bonds investors may seek to sell liquid stocks in order to save on transactions costs. Consequently in this scenario the price reaction to aggregate liquidity changes is stronger for more liquid stocks. Equally prices of liquid stocks could have greater sensitivity to aggregate liquidity shocks if such stocks are held in greater proportions within the portfolios of liquidity-conscious investors. Pastor and Stambaugh (2003) find little basis for liquidity betas to bear a simple relation to stock size and liquidity. Liu (2006) builds on this background in first using a new liquidity construct to estimate stock liquidity and then including 
this factor within a two factor augmented capital asset pricing model (CAPM). While the additional liquidity factor offers strong performance in explaining the cross section of US stock returns the findings are in contradiction to the earlier findings of Pastor and Stambaugh as the liquidity premium solely subsumes the documented anomalies such as size and the book-to-market effects from Fama and French (1993). The applied literature using these liquidity measures has grown rapidly recently with studies relating to Africa (Hearn and Piesse, 2009a, 2010), South East Asia (Shum and Tang, 2005) and the Spanish stock market (Martinez et al, 2005). These studies found evidence supporting the continued use of both size and liquidity factors in valuation. While investors would still require compensation from holding small size stocks owing to their additional risks as envisaged in Fama and French (1993) and while these stocks will likely be illiquid, the liquidity and size effects will be largely uncorrelated due to investors motivated to the most liquid stocks in the presence of uncertainty. I justify the use of both size and liquidity factors due to African emerging markets having well documented dispersions in both size and liquidity while investors, conscious of liquidity, are likely to invest in liquid stocks inferring a lack of correlation between size and liquidity effects. As such a three factor augmented CAPM model would build on the original work of Fama and French (1993), having found evidence of the existence of effects due to size and differences between value and growth stocks, known as the price-to-book effect, across the cross section of returns within the market universe. While I retain the size factor the additional liquidity factor is introduced following Martinez et al (2005) and further justified by the evidence of the importance of the liquidity effect over and above the Fama and French price-to-book factor from Pastor and Stambaugh (2003).

The majority of the valuation literature concerns the implementation of pricing models that assume a time invariant relationship in the systemic (market) risk of an asset. However over the last fifteen years a separate literature concerning the time varying nature of systemic risk has evolved from an increasing concerns of the violation of assumptions inherent in the linear model such as normality, identity and independence of stock returns (Grout and Zalewska, 2006). Pettengill et al (1995) studied the relationship between risk and return in "up" as opposed to "down" markets while Bekeart and Harvey (1995) undertook a similar study using Markovswitching regressions across a broad sample of emerging markets to examine differences between periods of integration with world market and segmentation. Brooks et al (1998) used time varying techniques based on the Kalman-filter approach and applied to Australian industry portfolios finding that these techniques produced improved in and out of sample performances than other econometric techniques. Grout and Zalewska (2006) find that the use of Kalman filter methods is preferable to Markov-switching regressions owing to their not having to define the exact point of the switch (Grout and Zalewska, 2006). Instead any changes in the time path of betas can be assessed through the study of regression results which is particularly relevant in the modelling of liquidity effects as these are prone to considerable fluctuation within emerging markets. In the light 
of this evidence I use time varying techniques employing the Kalman filter framework following Brooks et al (1998).

In this study I find evidence that liquidity and size factors are both significant in explaining cross section of returns and outperform the traditional CAPM. However the linear CAPM as well as its time-varying analogue have questionable performance in the presence of extreme illiquidity as is the case in Algeria and to a certain extent Tunisia. Models involving Algeria have very low explanatory power even though liquidity betas are statistically significant. Similarly the explanatory power of models applied to Tunisia, either with a North African or a Tunisian universe, also have low explanatory power. However the practical implications arising from cost of equity estimation indicate that Egypt has the highest costs of equity, followed by the very small Tunisian market with Morocco being the lowest inferring considerable benefits for Moroccan firms sourcing finance locally to engage in competitive international production. The profiles of the time varying liquidity betas indicate that the Moroccan and Egyptian equity markets have been affected by the 2008 global financial crisis while the more segmented Tunisian market has been relatively unscathed. These results support the continued use of the risk-return paradigm in valuation while finding it is limited in successful application to larger and more liquid stocks in the presence of extremes of size and illiquidity that are common in smaller emerging markets.

The paper is structured as follows. Section 2 reviews the institutional features of North African equity markets while section 3 outlines data sources before introducing the liquidity measures and their construction and finally descriptive statistics. Section 4 outlines the two modelling approaches used: the size and liquidity augmented CAPM and its time varying parameter analogue. Section 5 discusses the empirical results. The final section concludes and makes some comments on development policy that follows from the evidence presented in the paper.

\section{NORTH EQUITY MARKETS AND LIQUIDITY MEASUREMENT}

\section{(i). $\quad$ North African securities markets}

The principal characteristics of these markets are summarised below. A more detailed discussion of North Africa's financial markets is in Piesse and Hearn (2009a)

Egypt

The Egyptian stock exchange is both the oldest and largest financial market in the Maghreb region. The modern Cairo and Alexandria stock exchange (CASE) was formed through the integration of the Cairo exchange, established in 1903, and it's counterpart in Alexandria, established in 1888. In line with all other North African exchanges trading is electronic (CASE trading system, or CTS) although it is floor based with brokers orders being relayed to floor-based appointees for execution. Trading is undertaken in the main listed securities market between 11-30am and 15-30pm daily (see 
Table 1) and the market is fully G30 ${ }^{2}$ compliant. However despite a sizeable brokerage community of 147 licensed member firms, Table 1, only 30 account for over $70 \%$ of exchange order flow (CASE website, 2009). Furthermore order flow to the exchange is overwhelmingly dominated from investors using Cairo based brokers as opposed to Alexandria, where the former commonly accounts for over $92 \%$ of both buy and sell orders and even higher proportions of traded value and volume (see Table 2). The Egyptian equity market is split into several discrete compartments in order to attract listings. Each is differentiated on the basis of severity of regulatory criteria imposed on firms with the weakest being Nilex, which with a minimum number of issued shares of 100,000 and necessity of only 1 years audited financial statements (see Table 3), is aimed at attracting small and medium enterprises. These cannot afford to meet the more stringent and costly information disclosure requirements of the main market, which itself is split into official and unofficial compartments, themselves further split into another two sub compartments. The official compartment is reserved solely for indigenous Egyptian major public enterprises and the privatization of state owned enterprises or government divestitures with stringent regulation reflecting it's blue-chip status. The regulation weakens progressively in the upper tier of the unofficial market to the lower tier, with the latter only requiring one years audited financial statements and a mere EGP 5m paid up share capital.

There are several market barometer indices including CASE70 and the CASE All Share. There is significant sector concentration across both CASE70 and the overall market, although not to the same extent as the other North African markets. The evidence in Table 4 reveals that in line with the other Maghreb markets the financials sector dominates both capitalization $(27.05 \%$ for CASE70 and $24.81 \%$ for overall) and traded value (28.97\% for CASE70 and35.24\% for overall). There is also significant concentration of capitalization in the Basic Materials sector (14.45\%) and communications sector $(21.50 \%)$ in the overall market, revealing that extractive industries engaging in international production raise finance on the domestic exchange in contrast to Morocco or Tunisia.

\section{Tables 1, 2,3 and 4}

\section{Algeria}

The Bourse d'Alger, managed by the Société de Gestion de la Bourse des Valeurs (SGBV), was established in 1997 as a government initiative to boost private sector finance and attracted three listings in the following two years (Bourse d'Alger website, 2009). These were all privatizations of

\footnotetext{
${ }^{2}$ G30 relates to the Group of Thirty which is the most influential body to encourage the standardisation and improvement in global securities administration. Following a symposium in London in March 1989, the following recommendations were agreed: i) Brokers should match trades on day after deal date $(\mathrm{T}+1)$; ii) Trade confirmation on trade day plus 2 days $(\mathrm{T}+2)$; iii) Central Depository for safe keeping of shares; iv) Net basis settlement of cash and stock; v) Settlement takes place as delivery vs. payment or receipt vs. payment; vi) Settlement in same day funds; vii) Settlement effected on trade date plus 3 days $(T+3)$ 8; viii) Securities lending should be permitted; and ix) International securities numbering system must be adopted (ISIN code).
} 
state owned enterprises (SOE) and owing to the combination of a dominant banking sector, conservative business environment in respect of divulgence of private firm information, and a paucity in the application of universal accounting and auditing standards the exchange has been unable to attract any private sector firms (North Africa Times, 2008). The market is split into two trading compartments: "Le compartiment des valeurs mobilières" responsible for non-government issues of equity and bonds and "Les Obligations Assimilables du Trésor" covering government debt (Bourse d'Alger website, 2009). Trading is undertaken by electronic call auction with price "fixing" sessions (cours coté) on Monday and Wednesday for the former market segment and on Monday, Tuesday and Wednesday for the latter (see Table 1). The severity of the illiquidity caused the delisting of one of the three original listings and the tiny capitalization and traded value is evenly distributed between the two remaining stocks (see Table 4).

\section{Tunisia}

The Bourse de Tunis was established in 1969. Trading is electronic and was introduced in 1996 with the assistance of Euronext Paris. The trading system is split into fixing and continuous systems, with the former handling small and illiquid securities and comprised of a series of sequential electronic call auctions (Bourse de Tunis website, 2009). Trading hours in the continuous market are 9:00 am to 14:10 pm in the months outside July, August and during Ramadan where hours are 8:30 am to 12:10 pm (Table 1 and Bourse de Tunis website, 2009). Settlement is fully G30 compliant (see Table 1). The bourse has recently established an alternative market with relaxed regulation in order to attract listings (see Table 3 ) and in an effort to gain a greater prominence in the financing of the domestic business environment given only $5 \%$ of new finance was raised through the exchange in 2007 (Zribi, 2008). The exchange is small, with only 48 listings, and highly concentrated with $61.48 \%$ capitalization and $67.45 \%$ traded turnover in the financial sector alone (see Table 4). In an effort to further boost listings a range of tax breaks are offered to firms seeking to raise capital on the local bourse.

\section{Morocco}

The Bourse de Casablanca, Morocco, was established in 1929. Trading is by electronic continuous auction with terminals installed remotely in the small licensed network of brokers. Settlement is G30 compliant by MAROCLEAR, the national CSD established in 1998 (Bourse de Casablanca website, 2009). Formal corporate governance legislation, in the form of a Moroccan Code of Corporate Governance Practices, has only very recently been enacted in February 2007 through the establishment of a National Commission of Corporate Governance in Casablanca (European Corporate Governance Institute, 2009). However the exchange is hindered by similar problems in Algeria and Tunisia in it's limited ability to attract new listings. Consequently a range of tax breaks are offered to firms in order to reverse the limited stock market culture with a $50 \%$ reduction in 
corporation tax if a firm raises its share capital by at least $20 \%$ and relinquishes preferential subscription rights or a $25 \%$ reduction in tax through a standard flotation on the bourse (Bourse de Casablanca website, 2009). In line with Tunisia and Egypt the Moroccan bourse has three compartments differentiated by their varying levels of regulatory stringency. Regulation of the main market (marché principal) stipulates a minimum paid up and issued capitalization of MAD $75 \mathrm{~m}, 250,000$ shares in issue and 3 years of audited financial statements prior to listing (see Table 3). These criteria are subsequently weakened in the development market (marché développement) and growth market (marché croissance), the latter aiming to attract very small high growth firms (Bourse de Casablanca website, 2009). A reflection of the deeply conservative and entrenched business culture in Morocco, centred on dominant family control within firms, is the lack of any stipulation of minimum diversification or minimum number of shareholders. The overall market has 77 listed firms with the development market being the most concentrated with one firm alone accounting for $49.68 \%$ of capitalization (see Table 4 ). The financial and communications sectors account for over $67 \%$ of capitalization in the overall market and main market, while the consumer non-cyclical and financial sector account for over $60 \%$ of capitalization in the development and growth markets respectively.

\section{(ii). Liquidity constructs}

\section{The Bid Ask spread and commission cost}

The Bid Ask spread and commission cost: The data on the end of month bid and ask quotes were collected from Datastream. The bid-ask spread is calculated using the average of the available monthly quotes and incorporates at a minimum a single month's quote for that month. The average bid-ask spread spanning the month is used for the estimate of the spread. This procedure minimizes outlier problems and averages out the recording of either highs or lows in quotes resulting from monthly sampling. Following Lesmond (2005) bid-ask spreads that exceed $80 \%$ are trimmed as these are potentially errors. The monthly quoted spread is defined as:

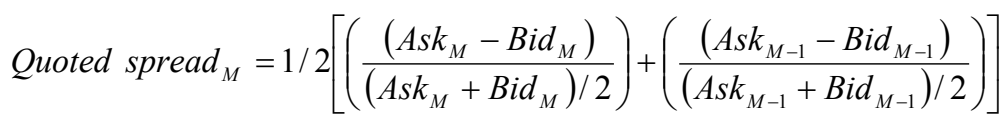

\section{Liu (2006) measure}

Daily price and volume data are collected from Datastream. The measure is derived from the recent work of Liu (2006) and is defined as $\mathrm{LM}_{\mathrm{x}}$ which is the standardized turnover-adjusted number of zero daily trading volumes over the prior $\mathrm{x}$ months $(\mathrm{x}=1,6,12)$ i.e.

$L M_{x}=\left[(\right.$ Number of zero daily volumes in prior x months $\left.)+\frac{1 / \mathrm{x} \text { month turnover }}{\text { Deflator }}\right] * \frac{21 x}{\text { NoTD }}$ 
where $\mathrm{x}$ month turnover is the turnover over the prior $\mathrm{x}$ months, calculated as the sum of the daily turnover over the prior $\mathrm{x}$ months, daily turnover is the ratio of the number of shares traded on a day to the number of shares outstanding at the end of the day, NoTD is the total number of trading days in the market over the prior x months, and Deflator is chosen such that,

$0<\frac{1 /(x \text { month turnover })}{\text { Deflator }}<1$

for all sample stocks ${ }^{3}$. Given the turnover adjustment (the second term in brackets in first expression), two stocks with the same integer number of zero daily trading volumes can be distinguished: the one with the larger turnover is more liquid. As such the turnover adjustment acts as a tie-breaker when sorting stocks based on the number of zero daily trading volumes over the prior $\mathrm{x}$ months. Because the number of trading days can vary from 15 to 23, multiplication by the factor (21x/ NoTD) standardizes the number of trading days in a month to 21 which makes the liquidity measure comparable over time. LM1 can be interpreted as the turnover-adjusted number of zero daily trading volumes over the prior 21 trading days, which is the approximate average number of trading days in a month. The liquidity measure, $\mathrm{LM}_{\mathrm{x}}$ is calculated at the end of each month for each individual stock based on daily data. Daily data is available for all markets across entire sample period.

\section{(iii). Data: Sources}

Daily stock closing, bid and ask prices, total number of shares outstanding, traded volumes, dividend per share in local currency and converted into UK£ were obtained for Egypt and Morocco from Datastream. These variables were sourced from both Bloomberg and the national stock exchanges for Algeria and Tunisia as well as Egypt and Morocco. These data formed the basis of calculation of the daily return variance, or volatility, market capitalization, defined as total number of shares outstanding multiplied by daily closing price, and various liquidity constructs. The total returns series for each stock were sourced direct from Datastream for Morocco and Egypt while they had to be constructed for Algeria, Tunisia and those stocks where this variable was missing in the case of Egypt using the procedures employed by Standard \& Poors in assuming reinvestment of dividends and taking account of stock splits, rights issues and other corporate actions affecting a stocks intrinsic value. Exchange rate and UK- Gilt/Treasury yield data are sourced from Datastream. The one-month UK-Gilt/Treasury Bill yield rate represents the risk free rate although this is adjusted to take account of monthly excess returns as opposed to the quoted equivalent annualised rates. The conversion of the total returns series and prices into sterling and the use of UK - Gilt/Treasury yield rate assumes long term parity between individual domestic currencies and sterling.

\footnotetext{
${ }^{3}$ In line with Liu (2006) a deflator of 1,000 is used in constructing estimates for LM1
} 


\section{(iv). Data: Summary statistics relating to liquidity measures}

The considerable differences in liquidity, size and activity between sectors, listing compartments and national markets can be clearly seen from Table 5 . This contrasts the mean cross section values for daily percentage zero returns, stock prices, traded volumes, market capitalization and bid-ask spreads for the component firms within the Maghreb markets. These are further sub-divided into the three major listings compartments for Morocco, main, development and growth, the two major index groups for Egypt, CASE70 and Overall, and into major industry categories where industries accounting for only a fraction of capitalization and traded value, namely under $5 \%$ of the total, are omitted. There is clear evidence of a likely size effect in all markets with considerable variations in the cross sectional mean capitalization of firms between industry categories and between these and the overall market. Similarly there is a considerable dispersion in the bid-ask spread although this decreases in value as size increases indicating an association between size and liquidity. The percentage of daily zero returns variable, another measure of liquidity through price-rigidity, is highest for Algeria (95.66\%) and then for Tunisia (73.83\%) and all Tunisian industrial sectors, where the most liquid, communications, has a value of $41.67 \%$. These extremely high values provide indication that a different valuation methodology should be applied to the smallest and least liquid markets. It is also indicative of the significant segmentation apparent both between and within North African markets and provides further justification for this study in it's contrasting individual market universes for each of the countries in turn, bar Algeria where there are too few stocks to achieve diversification, against an aggregate North African universe.

\section{Table 5}

\section{EMPIRICAL MODELS}

This section considers two conditional modelling strategies, namely the three-factor linear CAPM and its time varying parameter counterpart.

\section{(i). Size and Liquidity Augmented CAPM}

Following in the spirit of Fama and French (1993) I augment the one-factor CAPM with size (SMB) and liquidity (ILLIQ) factors. Therefore, the expected excess returns on a portfolio $\mathrm{p}$ of emerging market stocks can be written as

$$
E\left(r_{p t}\right)-r_{f t}=\beta_{p}\left[E\left(r_{m t}\right)-r_{f t}\right]+s_{i} E(S M B)+h_{i}(I L L I Q)
$$

The equilibrium relation of the three factor model is stated in terms of expected returns. In order to test the model with historical data, it is necessary to transform (4) to the following estimating equation:

$$
r_{i t}-r_{f t}=\alpha_{i}+\beta_{i}\left(r_{m t}-r_{f t}\right)+s_{i} S M B_{t}+h_{i} I L L I Q_{t}+\varepsilon_{i t}
$$


where the variables are described above and $\varepsilon_{i t}$ is an independently identically distributed (iid) disturbance term. The model is estimated on a time series basis using standard Ordinary Least Squares (OLS) techniques, as opposed to the Fama and Macbeth (1973) rolling cross section approach, with the expectation that the Jensen alpha, or regression intercept, should not be statistically different from zero given the theoretical relationship between an individual portfolios expected returns and those of the market (Markowitz, 1959). However Scholes and Williams (1977) provide evidence against the employment of standard OLS techniques with findings that beta estimations are biased downwards for securities infrequently trading and upwards for those traded more often. Dimson (1979) builds on this evidence in the inefficiency of beta estimation in thinly traded stocks and proposes a correction technique based on the aggregation of betas from lagged and leading regression coefficients. Dimson and Marsh (1983) propose a second correction technique which uses a trade-to-trade method measuring and matching returns between individual stocks or portfolios and the market index between the times of the last trades in successive months. I justify the use of standard OLS techniques here in order to closely follow the literature of Pastor and Stambaugh (2003), Liu (2006) and Martinez (2005) who use these techniques extensively in their studies involving multifactor CAPM models capturing liquidity effects. However the limitations of standard OLS techniques must be taken into account when they are applied to the very illiquid markets such as Algeria and Tunisia.

\section{(ii). Time varying parameter CAPM model}

Following Brooks et al (1998) the time varying parameter analogue of the linear CAPM employs the Kalman filter and relies on the notion of "state space" in estimating the conditional constant term and market beta of the multifactor analogue of CAPM. This is represented by an observation, or measurement/signal, equation and a transition, or state, equation, that in combination express the structure and dynamics of a time varying system. A state space model is specified where an observation at time $t$ is a linear combination of a set of variables, known as state variables, which compose the state vector at time t. Assuming the number of state variables is $\mathrm{m}$ and the $(\mathrm{m} \times 1)$ vector is $\theta_{\mathrm{t}}$ then the observation equation can be represented by:

$$
y_{t}=z_{t} \theta_{t}+\mu_{t}, \quad \mu_{t} \sim N\left(0, \sigma_{\mu}^{2}\right)
$$

where $z_{t}$ is assumed to be known ( $\mathrm{mx} 1$ ) vector, and $\mu_{t}$ is the observation error. The disturbance $\mu_{t}$ is assumed to be normally distributed with zero mean. The set of state variables is defined from the minimum set of information from past and present data and future values of time series are completely determined by the present values of the state variables, known as the Markov property. The state space model incorporates unobserved variables within, and estimates them alongside the 
observable model, in imposing a time varying structure of the CAPM beta. The conditional betas are estimated using the following observation, or signal equation:

$$
R_{i t}=\alpha_{t}+\beta_{i t}^{\text {Kalman }} R_{M t}+s_{i}{ }^{\text {Kalman }} S M B+h_{i}^{\text {Kalman }} I L L I Q+\varepsilon_{t}, \quad \varepsilon_{t} \sim N(0, \Omega)
$$

where $\mathrm{R}_{\mathrm{it}}$ and $\mathrm{R}_{\mathrm{Mt}}$ are the excess returns of individual portfolio and market portfolios at time $t$ and $\varepsilon_{t}$ is disturbance term. The exact form of the related transition equation depends on the form of stochastic process the betas are assumed to follow and in this case a simple random walk process is imposed as outlined in Brooks et al (2000). The transition equation is defined:

$$
\begin{array}{ll}
\alpha_{i t}^{\text {Kalman }}=\alpha_{i t-1}^{\text {Kalman }}+\eta_{\alpha t,} & \eta_{\alpha t} \sim N(0, Q) \\
\beta_{i t}^{\text {Kalman }}=\beta_{i t-1}^{\text {Kalman }}+\eta_{\beta t}, & \eta_{\beta t} \sim N(0, Q) \\
s_{i t}^{\text {Kalman }}=s_{i t-1}^{\text {Kalman }}+\eta_{s t}, & \eta_{s t} \sim N(0, Q) \\
h_{i t}^{\text {Kalman }}=h_{i t-1}^{\text {Kalman }}+\eta_{h t,}, & \eta_{h t} \sim N(0, Q)
\end{array}
$$

Together equations 7 and the combination of 8 to 11 constitute a Kalman filter state space model. However a set of prior conditional values are necessary for the Kalman filter to forecast the future value and is expressed as:

$$
\begin{aligned}
& \alpha_{0}^{\text {Kalman }} \sim N\left(\alpha_{0}^{\text {Kalman }}, P_{0}\right) \\
& \beta_{0}^{\text {Kalman }} \sim N\left(\beta_{0}^{\text {Kalman }}, P_{0}\right) \\
& s_{0}^{\text {Kalman }} \sim N\left(s_{0}^{\text {Kalman }}, P_{0}\right) \\
& h_{0}^{\text {Kalman }} \sim N\left(h_{0}^{\text {Kalman }}, P_{0}\right)
\end{aligned}
$$

Brooks et al (1998) cite that this technique uses the first two observations to establish the prior conditions and then recursively estimates the entire series providing conditional estimates of $\beta_{i t}^{\text {Kalman }}, s_{i t}^{\text {Kalman }}, h_{i t}^{\text {Kalman }}$ and $\alpha_{i t}^{\text {Kalman }}$.

\section{RESULTS}

(i). Summary statistics relating to size-liquidity sorted portfolios

The dispersion of stocks on a market by market basis between the nine size-illiquidity sorted portfolios, together with portfolio descriptive statistics is given in Table6. These have been generated separately for each of the market universes, i.e. the aggregate North African universe and then for Morocco, Tunisia and Egypt individually. There is a relatively even dispersion of stocks across size-liquidity sorted portfolios for the larger North African regional universe as well as for the larger individual market universes of Egypt and Morocco, while in the Tunisian universe there is a greater number of stocks concentrated in the three low illiquidity portfolios and fewer stocks in the medium and high illiquidity portfolios. This is likely to reflect the additional lack of individual 
stock size and liquidity information for the extremely inactive stocks, a reflection of their greater uncertainty, which causes their omission in the size-liquidity sorting process.

The mean and median returns across all size-liquidity sorted portfolios are positive, with sole exception of the Egyptian big size - high illiquidity portfolio, for all markets except Tunisia, reflecting the effects of liquidity. This is also reflected in the measure of volatility, where standard deviations increase dramatically from larger size firm to smaller size firm portfolios. Average returns in small size stock portfolios tend to be more risky than in larger stock portfolios, but also have higher potential returns. Furthermore standard deviations in Tunisia are considerably greater than for either Morocco or Egypt or the aggregate North African universe and are over 30\% for the big size - medium and high illiquidity portfolios (see Table 6). Equally the Tunisian portfolios have the highest degree of skewness and kurtosis indicating that assumptions of Normality in the returns series are questionable and indicating both the degree of segmentation of this market with other Maghreb markets and that different valuation techniques should be applied in the presence of such extremes of illiquidity. However the lack of viable alternative methodologies and the ease of application merit the continued use of this methodology in this study.

\section{Table 6}

Descriptive statistics for all overall market, industry and listings compartment portfolios as well as the zero-cost SMB and ILLIQ portfolios are in Table 7. These reveal that industry portfolios have generally positive excess returns with the exception of Tunisia where apart from the financial sector all industries have negative excess returns. However the greatest variations in skewness and kurtosis arise amongst the Egyptian and Moroccan industry portfolios. Egyptian Industrials and Moroccan consumer cyclical sectors have the highest levels of kurtosis and skewness, with 11.792 and 2.221 for the former, and 14.689 and 2.424 for the latter (see Panel A in Table 7).

The descriptive statistics for the valuation factors are shown in panel B of Table 7. These reveal that across all market universes (Tunisia, Morocco, Egypt and North Africa) the mean of the market variable is positive. However the means of the size factor in Tunisia, Morocco and Egypt indicates the likelihood of a reverse size effect from that in Fama and French (1993) where returns steadily decrease as stock size increases. The evidence also shows that there is little correlation between the SMB, ILLIQ and Market valuation factors for the market variables of Morocco and Egypt inferring little correlation between underlying state variables within each universe. Contrastingly there is some correlation between the illiquidity and market factors within the North African markets and between the market and size factors in the Tunisian market.

Table 7 
Table 8 reports the results from the grouped pooled regression on all nine size-illiquidity sorted portfolios for each of the market variables: Egypt, Morocco, Tunisia and North Africa. In all cases there is an increase in explanatory power arising from the augmentation of the traditional CAPM with the size and liquidity factors. Equally the Jensen alpha, $\alpha_{p}$, term was not statistically significantly different from zero for both the traditional CAPM and it's three factor counterpart, with the sole exceptions of the medium size-medium illiquidity portfolio in the Egyptian universe and the medium size-low illiquidity portfolio in the North African universe, where the statistical significance of the regression alpha was lost following the addition of the size and illiquidity factors. This would indicate a good fit with theory. The coefficients on the large-size portfolios are negative as well as being highly statistically significant in the Moroccan, Egyptian and North African universes. Tunisia is similar but less profound with negative size betas on only the big size - medium and high illiquidity portfolios.. The negative sign on the large-size portfolio betas indicates that large firms' returns decrease when the size premium increases, which is the opposite for small firms. This behaviour is not expected and is indicative of a reversal of the documented "size effect" that effects the valuation of smaller firms (Martinez et al, 2005). It is also a feature of an extremely heterogeneous universe of stocks, where there are considerable differences in stocks within markets as evidenced from the descriptive statistics in Table 5. This is the opposite of what would be expected and does not provide investors with good hedging opportunities. Thus, as with the results for the small-size portfolios, a different valuation method would be needed to price very high illiquidity stocks and firms accurately. The estimated coefficients on the illiquidity factormimicking portfolios are negative for low and medium-illiquidity portfolios indicating as expected that more liquid firms experience a decrease in expected returns when aggregate market illiquidity increases. In general, the coefficients on the low-illiquidity and medium-illiquidity portfolios are negative, as one would expect, with firms paying lower returns when the illiquidity variable increases. However, the coefficients on the high-illiquidity portfolios are positive indicating that these companies pay higher returns when the illiquidity measure increases. The increased explanatory power of these models illustrates that the augmented CAPM is appropriate for illiquid markets.

However in the case of Tunisia the levels of explanatory power are frequently less than those of any of the other market universes. The severity of illiquidity issues affecting the model is highlighted in the adjusted $\mathrm{R}^{2}$ of $2.73 \%$ for the small size high illiquidity portfolio in the one-factor model which leaps to $28.39 \%$ upon the inclusion of the size and liquidity factors. A similar dramatic increase in explanatory power from the inclusion of the size and liquidity factors arises in the large size high illiquidity portfolio where the adjusted $\mathrm{R}^{2}$ in the one-factor model is $50.99 \%$ and increases to $82.98 \%$. Although the application of this model to highly illiquid markets is questionable and the implicit assumptions regarding inter and intra asset market integration are very 
tenuous these are important results in the context of emerging markets, as the vast majority of research on the original of Sharpe (1964) and Lintner (1965) is confined to developed markets.

The estimated coefficients on both the market excess return $(\hat{\beta})$ and the illiquidity factor (ILLIQ) are large and significant in almost all cases. Those on the size factor-mimicking portfolio (SMB) are smaller in the majority of cases and are only significantly different from zero in the large or small-size company portfolios.

\section{Table 8}

\section{(iii) Modelling industry portfolios and cost of equity estimation}

Country and industry portfolios were formed from the simple price-weighted averages of stock returns across stocks aggregated into either industries or countries. The time invariant CAPM, sizeilliquidity and size-price-to-book value augmented CAPM models were applied to the portfolios with results reported in Table 9.

\section{Average Returns in Algeria}

Algeria was modelled using the aggregate North African universe due to its very small size. However the effects of extreme illiquidity are immediately apparent with the traditional CAPM having almost negligible explanatory power of less than $1 \%$ which marginally increases upon the addition of the size and liquidity factors to approximately $6 \%$. Additionally almost all the coefficients are not statistically significant from zero at a $90 \%$ confidence level further indicating the poor fit of this model in the presence of such extreme of illiquidity.

\section{Average Returns in Tunisia}

Tunisia was modelled using both an aggregate North African and Tunisian market universe (Table 9). The results are similar to those of Algeria though much less profound with significant improvements in explanatory power and statistical significance of betas when the aggregate North African universe is replaced by a Tunisian counterpart. Explanatory power (adjusted $\mathrm{R}^{2}$ ) for the traditional CAPM using the North African universe is less than $8 \%$ which only marginally increases through the addition of the size and liquidity factors, with the prominent exception of Diversified (an increase to $90.29 \%$ ), Consumer cyclical (an increase to 16.77\%), Financial (an increase to $23.05 \%$ ) and the overall market (an increase to $22.82 \%$ ). In these cases the size and liquidity betas are both large and significant indicating returns are driven by these factors. In contrast the evidence from when the model is applied to the Tunisian universe is that explanatory power in the traditional CAPM is over 50\% for Financial, Consumer cyclical and Industrial sectors and over 30\% for Diversified. The additional size and liquidity factors cause almost no increase in explanatory power of the resulting three factor model and the size and liquidity betas in each case are not statistically 
different from zero. This is further evidence that distortions are so severe due to illiquidity that the Tunisian market is significantly segmented from the other major North African markets.

\section{Average Returns in Egypt}

The most noticeable change between the use of the aggregate North African universe its Egyptian counterpart is the considerable decrease in statistical significance of the additional size and liquidity betas in the three factor model. Furthermore there are only slight increases in explanatory power across industry portfolios when the Egyptian-only universe is used. There is also a decrease in the absolute size of coefficients when the North African universe is replaced with Egypt. Liquidity betas are large and negative when the former universe if applied for Financial, Communications, Basic Materials, and CASE70 constituents, and decrease in value with Basic Materials losing significance at $90 \%$ confidence level in the Egyptian universe. Consequently the market factor plays a greater role in explaining returns within the Egyptian universe than in its North African counterpart with less importance attached to size and liquidity. Although the differences between the two universes are not as pronounced as with Tunisia these results do highlight the tenuous assumptions of full asset market integration across the wider North African universe and region.

\section{Average Returns in Morocco}

The differences arising from the use of either the North African aggregate universe or it's local counterpart are very pronounced with Morocco. In contrast to Egypt and Tunisia the replacement of the North African universe with its Moroccan counterpart does not result in changes in the size and significance of size and liquidity betas. However while these retain their importance in explaining local returns across industries and the three listings compartments (main, development and growth markets) the explanatory power of the three factor model substantially increases. The adjusted $\mathrm{R}^{2}$ for the main, development and growth markets are $32.47 \%, 19.70 \%$ and $9.75 \%$ respectively in the North African universe compared to $94.70 \%, 67.97 \%$ and $53.93 \%$ when using the Moroccan universe. Similar substantial increases in explanatory power in the three factor models are found for all Moroccan industry portfolios highlighting the lack of integration between the local market and its regional counterpart.

\section{Table 9}

\section{Modelling industry portfolios with time varying techniques}

The time varying coefficient model based on the augmented CAPM was only estimated including market, size and illiquidity factors. The evidence in Table 10 provide some support to the findings of the preceding section where maximum likelihood convergence in the highly illiquid market sectors of Algeria, Morocco's development market and Tunisia's consumer non-cyclical and overall markets is achieved using only alpha, market and illiquidity factors. This would provide 
some support that illiquidity factor does have an important role in valuation using this time varying methodology.

\section{Table 10}

Figures 1 to 7 provide time series plots of the evolution of the liquidity betas across the overall market portfolios in each case as well as portfolios for CASE70 in Egypt, and the three listings compartments in Morocco (main, development and growth). The evidence from the overall markets in Figures 1 (Morocco), 5 (Tunisia) and 6 (Egypt) reveals that there have been significant changes in the size, direction and significance of liquidity betas for Morocco and Egypt since the onset of the global financial crisis and recession in 2007/2008. This is further highlighted from an examination of Figure 7, documenting the liquidity beta of CASE70 constituents. The time profile of the liquidity beta for Tunisia is markedly different and moves close to zero with a negative lower band of standard error indicating lack of statistical significance of the beta. These results would be expected given that Morocco and Egypt are more internationally focussed markets attracting significant amounts of foreign investment while Tunisia is much smaller and classed as a Frontier emerging market by Standard \& Poors (Standard \& Poors website, 2009).

Study of Figures $1-4$ reveal differences in liquidity between the overall Moroccan market and it's three component listing compartments. The time profile of the liquidity beta for the Moroccan market, in Figure 1, closely resembles that of the main listings compartment (Marche Principal), in Figure 2, while the profiles of the development (Figure 3) and growth (Figure 4) are substantially different from the main board. However all market segments reflect a considerable increase in size and significance of the liquidity beta since 2007/2008.

\section{Figures 1 - 7}

\section{(iv) Costs of equity estimation}

Table 11 reports estimates of the cost of equity calculated from the expected returns from each country, industry and listings compartment regression. Estimates are calculated using regression based techniques from each of the individual country universes as well as the North African universe and then using time varying techniques using the regional universe only. Although there is considerable variation in the cost of equity between sectors within and between markets, Tunisia and Egypt have the highest while Morocco and Algeria have the lowest. However although the very low values for Algeria seem counterintuitive when considering the extremes of illiquidity and inactivity in the market, they are largely in line with those used originally to discount the expected cash flows of the two listed firms in calculating the offer price per share at listing (COSOB website, 2009). However while there are small differences between the estimates generated from individual country and regional universes, the most significant differences arise between the time invariant regression techniques and the time varying methods. This is exemplified by the low costs of equity 
in the basic materials industries between Egypt, Morocco and Tunisia as estimated by the former time invariant method while estimates using the latter time varying methods regard this industry as having the highest values which is in line with previous research (Hearn and Piesse, 2010a).

\section{Table 11}

\section{CONCLUSIONS}

This study proposes to augment the traditional CAPM and it's time varying counterpart with additional returns based size and liquidity factors that mimic underlying state variables present within a universe of stocks. The recently developed Liu (2006) liquidity measure is used to capture the multi-dimensional nature of liquidity, although it has particular strength in measuring trading speed, a particularly prominent feature in emerging markets where there are considerable variations in time between order submission and trade execution. The valuation models are applied across individual country universes as well as a regional universe for the equity markets of the North African Maghreb region, namely Algeria, Egypt, Morocco and Tunisia. The implications of the study in terms of comparative costs of equity faced by firms within various industry sectors seeking to raise cost effective finance adds additional value to the findings. An additional benefit from the application of time varying techniques is that a study of the effects of the 2007/2008 global financial crisis on domestic North African industries can be undertaken.

The application of both the multifactor CAPM and time varying coefficient models reveals the relative contributions of the market, size and liquidity premiums in the conditional modelling of the returns generating process across size and liquidity sorted portfolios. While the very small size and extreme illiquidity questions the application of these valuation techniques on Algeria, there is considerable evidence regarding the segmentation of individual markets from a regional aggregated North African universe. The explanatory power arising from the addition of size and liquidity factors increases across all markets, industries and listings compartments when using the regional universe. However in Egypt and Tunisia the importance of the size and liquidity factors declines substantially when the regional universe is replaced with its domestic country counterpart with only a marginal effect on explanatory power. In contrast there is persistent evidence that returns in Morocco are driven by size and liquidity whether at a regional or national level.

Similar findings arise from the application of time varying Kalman filter techniques, albeit using a regional universe. However the time varying profiles of liquidity betas reveal that the more internationally focussed markets of Morocco and Egypt have been affected by the 2007/2008 global financial crisis with betas increasing in size and significance. These results provide some support for the continued use of the risk-return paradigm in emerging markets although this is limited to larger more liquid markets in the presence of extremes of illiquidity. The evidence from the estimates of costs of equity reveals that these are highest in Tunisia and Egypt, where returns in the former are driven by a considerable liquidity premium alone. There are considerable differences in 
cost of equity both across markets and between component industries providing further evidence of the degree of segmentation present in North African equity markets. 


\section{REFERENCES}

Amihud, Y., 2002, Illiquidity and stock returns: cross section and time series effects. Journal of Financial Markets 5, 31-56.

Amihud, Y. and H. Mendelson, 1986, Asset pricing and the bid-ask spread. Journal of Financial Economics 17, 223-249.

Brooks, R. D., R.W. Faff and M. D. McKenzie, 1998, Time-varying beta risk of Australian industry portfolios: A comparison of modelling techniques. Australian Journal of Management 23(1), $1-22$.

Bourse d'Alger website, 2009, Bourse d'Alger. http://www.sgbv.dz/ Accessed 20 December 2009

Bourse de Casablanca website, 2009, Bourse de Casablanca. http://www.casablanca-bourse.com/ Accessed 20 December 2009

Bourse de Tunis website, 2009, Bourse de Tunis. http://www.bvmt.com.tn/ Accessed 20 December 2009

CASE website, 2009, The Egyptian Exchange. http://www.egyptse.com/English/homepage.aspx Accessed 20 December 2009

COSOB website, 2009, La Commission d'Organisation et de Surveillance des Opérations de Bourse (COSOB). http://www.cosob.org/ Accessed 20 December 2009

Datar, V. T., N. Y. Naik and R. Radcliffe, 1998, Liquidity and stock returns: An alternative test. Journal of Financial Markets 1, 203-219.

Dimson, E., 1979, Risk measurement when shares are subject to infrequent trading. Journal of Financial Economics 7, 197-226.

Dimson, E. and P. Marsh, 1983, The stability of UK risk measures and the problem of thin trading. Journal of Finance 38, 753-783.

El-Khatib, Y., 2008, Interview with Yasmin El-Khatib, Senior Public Relations Manager, Cairo and Alexandria Stock Exchanges, Cairo, Egypt. 25 February 2008.

European Corporate Governance Institute, 2009, National Commission on Corporate Governance: Royaume du Maroc. http://www.ecgi.org/codes/documents/morocco_code_march2008_en.pdf Accessed 20 December 2009

Fama, E. F. and K. French, 1993, Common risk factors in the returns on stocks and bonds. Journal of Financial Economics 33, 3-56.

Fama, E. F. and J. D. Macbeth, 1973, Risk, return and equilibrium: empirical tests. Journal of Political Economy 81, 607-636.

Grout, P. A. and A. Zalewska, 2006, The impact of regulation on market risk. Journal of Financial Economics 80, 149-184. 
Hearn, B., J. Piesse, and R. Strange, 2009, Overcoming Financing Constraints to Corporate Expansion: Evidence from a Company in an Emerging Islamic Market. Transnational Corporations 18(3), 1-26

Hearn, B. and J. Piesse, 2009a, Sector level cost of equity in African financial markets. Emerging Market Review 10, 257-278

Hearn, B., and J. Piesse, 2010a,. Performance of Size and Liquidity portfolios in West Africa. Applied Financial Economics, forthcoming

Kuran, T., 2004, Why the Middle East is economically underdeveloped: historical mechanisms of institutional stagnation. Journal of Economic Perspectives 18(3), 71-90.

Kuran, T., 2005, The logic of financial westernization in the Middle East, Journal of Economic Behaviour \& Organization 56(1), 593-615.

La Porta, R., F. Lopez-de-Silanes, and A. Shleifer, 2008, The Economic Consequences of Legal Origins, Journal of Economic Literature 46, 285-332

Lee, C., 1993, Market fragmentation and price-execution in NYSE-listed securities. Journal of Finance 48, 1009-1038.

Lesmond, D. A. (2005) Liquidity of emerging markets. Journal of Financial Economics, 77, 411452.

Libyan stock exchange website, 2009, Libyan stock market. http://libyastockmarket.com/Index_En.asp Accessed 20 December 2009

Lintner, J., 1965, The valuation of risk assets and the selection of risky investments in stock portfolios and capital budgets. Review of Economics and Statistics 17, 13-37.

Liu, W., 2006, A Liquidity-augmented capital asset pricing model. Journal of Financial Economics 82, 631-671.

Markowitz, H., 1959, Portfolio Selection: Efficient Diversification of Investments. New York: John Wiley and Sons; London: Chapman and Hall.

Martinez, M. A., B. Nieto, G. Rubio and M. Tapia, 2005, Asset pricing and systematic liquidity risk: An empirical investigation of the Spanish stock market. International Review of Economics and Finance 14, 81-103.

NEPAD website, 2009, New Partnership for Africa's Development. http://www.nepad.org/home/lang/en Accessed 20 December 2009

North Africa Times, 2008, Algiers Bourse Shunned by Private Sector Regulator. North Africa Times Business, Sunday 16-22/3/2008. http://www.alarab.co.uk/Previouspages/North\%20Africa\%20Times/2008/03/0316/NAT091603.pdf Accessed 20 December 2009

O’Hara, M., 2003, Presidential address: liquidity and price discovery. Journal of Finance 58, 13351354 
Pastor, L. and R. Stambaugh, 2003, Liquidity risk and expected stock returns. Journal of Political Economy 111, 642-685.

Pettengill, G., S. Sundaram, and I. Mathur, 1995, The conditional relation between beta and returns. Journal of Financial and Quantitative Analysis 30: 101-116.

Scholes, M. and J. T. Williams, 1977, Estimating betas from nonsynchronous data. Journal of Financial Economics 5: 309-327.

Sharpe, W. F., 1964, Capital asset prices: A theory of market equilibrium under conditions of risk. Journal of Finance 19, 425-442.

Shum, W. C., and G. Y. N. Tang, 2005, Common risk factors in returns in Asian emerging stock markets. International Business Review 14, 695-717.

Standard \& Poors website, 2009, Standard \& Poors. http://www.standardandpoors.com/home/en/us Accessed 20 December 2009

Zribi, H., 2008, Interview with Hatem Zribi, Market Development, Bourse de Tunis, Tunisia. 18 January 2008. 
Table 1 Contrast of market trading and institutions

\begin{tabular}{|c|c|c|c|c|c|c|}
\hline & Commercial Law & $\begin{array}{l}\text { No. } \\
\text { Brokers }\end{array}$ & $\begin{array}{l}\text { Market Clearance } \\
\text { Procedures }\end{array}$ & $\begin{array}{l}\text { Capital } \\
\text { Gains Tax }\end{array}$ & Trading Hours & Trading Arrangements \\
\hline Morocco & Civil code & 15 & $\begin{array}{l}\text { Fully G30 compliant } \\
\text { including custodial } \\
\text { facilities. DVP } \\
\text { undertaken } \mathrm{T}+3 \text {. }\end{array}$ & Exempt & $\begin{array}{l}\text { 9-00am - 9-30am: Pre-Open } \\
\text { 9-30am - 15-30pm: Cont. Trading } \\
\text { 15-30pm-16-00pm: Pre-Close }\end{array}$ & $\begin{array}{l}\text { Delocalized Electronic quote } \\
\text { driven trading system - NCS. }\end{array}$ \\
\hline Tunisia & Civil code & 24 & $\begin{array}{l}\text { Fully G30 compliant } \\
\text { including custodial } \\
\text { facilities. DVP } \\
\text { undertaken } \mathrm{T}+3 \text {. }\end{array}$ & Exempt & $\begin{array}{l}\text { 9-00am to 10-00am: Pre-opening } \\
\text { 10-00am - 11-30am Trading Session }\end{array}$ & $\begin{array}{l}\text { Delocalized Electronic order } \\
\text { matching system. Terminals } \\
\text { installed remotely at local brokers. }\end{array}$ \\
\hline Algeria & Civil code & 11 & $\begin{array}{l}\text { Partial G30 compliant. } \\
\text { DVP undertaken } \mathrm{T}+3\end{array}$ & Exempt & $\begin{array}{l}\text { Twice per week: Mondays and Wednesdays (Monday, } \\
\text { Tuesday and Wednesday for Gvt. Treasury instruments) } \\
\text { 9-30am: Opening of session } \\
\text { 10-15am: Placement and registration of orders } \\
\text { 10-40am: Call auction (price fixing) for all counters } \\
\text { 11-50am: Second Call auction for "March blocs" (block } \\
\text { transactions) } \\
\text { 11-05am: Publishing of results } \\
\text { 11-15am: Session close }\end{array}$ & $\begin{array}{l}\text { Le fixing (cours coté): Electronic } \\
\text { call auction, or price fixing session }\end{array}$ \\
\hline Egypt & Civil code & 146 & $\begin{array}{l}\text { Fully G30 compliant } \\
\text { including custodial } \\
\text { facilities. DVP } \\
\text { undertaken } T+3 \text {. }\end{array}$ & Exempt & Listed Securities Market: 11-30am - 15-30pm & $\begin{array}{l}\text { Exchange based Automated trading } \\
\text { system CASE - The CASE Trading } \\
\text { System, or CTS }\end{array}$ \\
\hline
\end{tabular}


Table 2 Market microstructure of Egypt's Cairo and Alexandria Stock Exchange

\begin{tabular}{|c|c|c|c|c|c|c|c|c|}
\hline & Order Type & Daily Average & 2004 & 2005 & 2006 & 2007 & 2008 & 2009 \\
\hline \multirow{17}{*}{ Cairo Floor } & \multirow{8}{*}{ Buy } & \multirow{2}{*}{ Value } & $130,204.24$ & $552,386.92$ & $1,035,164.98$ & $1,196,957.30$ & $1,831,229.59$ & $890,047.16$ \\
\hline & & & {$[104,264.93]$} & {$[380,551.62]$} & {$[805,636.35]$} & {$[993,906.57]$} & {$[1,265,922.64]$} & {$[728,437.16]$} \\
\hline & & $\%$ Total & $96.38 \%$ & $96.59 \%$ & $96.95 \%$ & $97.75 \%$ & $97.96 \%$ & $95.59 \%$ \\
\hline & & \multirow{2}{*}{ Volume } & 6,697 & 15,957 & 30,281 & 44,698 & 86,544 & 117,919 \\
\hline & & & {$[5,994]$} & {$[11,604]$} & {$[27,022]$} & {$[38,474]$} & {$[75,204]$} & {$[99,331]$} \\
\hline & & $\%$ Total & $93.53 \%$ & $94.80 \%$ & $95.37 \%$ & $96.04 \%$ & $96.34 \%$ & $94.84 \%$ \\
\hline & & \multirow{2}{*}{ No. Orders } & 6,220 & 14,799 & 25,105 & 33,697 & 49,642 & 53,829 \\
\hline & & & {$[5,993]$} & {$[11,236]$} & {$[24,704]$} & {$[32,517]$} & {$[47,723]$} & {$[50,578]$} \\
\hline & \multirow{9}{*}{ Sell } & \multirow{2}{*}{ Value } & $130,211.31$ & $553,810.96$ & $1,035,489.83$ & $1,194,093.44$ & $1,834,195.34$ & $889,383.31$ \\
\hline & & & {$[105,641.14]$} & {$[381,497.74]$} & {$[804,621.86]$} & {$[993,950.02]$} & {$[1,265,319.8]$} & {$[732,584.13]$} \\
\hline & & $\%$ Total & $96.39 \%$ & $96.84 \%$ & $96.98 \%$ & $97.51 \%$ & $98.12 \%$ & $95.52 \%$ \\
\hline & & \multirow{2}{*}{ Volume } & \multirow{2}{*}{$6,708[5,937]$} & 16,025 & 30,311 & 44,647 & 86,852 & 117,719 \\
\hline & & & & {$[11,475]$} & {$[27,160]$} & {$[38,556]$} & {$[75,686]$} & {$[99,079]$} \\
\hline & & $\%$ Total & $93.69 \%$ & $95.21 \%$ & $95.47 \%$ & $95.93 \%$ & $96.68 \%$ & $94.68 \%$ \\
\hline & & \multirow{2}{*}{ No. Orders } & 6,217 & 15,033 & 25,194 & 33,640 & 49,851 & 53,895 \\
\hline & & & {$[5,960]$} & {$[11,151]$} & {$[24,905]$} & {$[32,455]$} & {$[48,159]$} & {$[50,883]$} \\
\hline & & $\%$ Total & $92.41 \%$ & $93.77 \%$ & $93.21 \%$ & $94.22 \%$ & $95.40 \%$ & $94.55 \%$ \\
\hline \multirow{14}{*}{ Alexandria Floor } & \multirow{7}{*}{ Buy } & \multirow{2}{*}{ Value } & $4,886.70$ & $19,494.98$ & $32,562.81$ & $27,598.03$ & $38,127.77$ & $41,086.07$ \\
\hline & & & {$[4,226.79]$} & {$[12,489.93]$} & {$[29,253.69]$} & {$[26,026.94]$} & {$[35,291.88]$} & {$[34,751.32]$} \\
\hline & & $\%$ Total & $3.62 \%$ & $3.41 \%$ & $3.05 \%$ & $2.25 \%$ & $2.04 \%$ & $4.41 \%$ \\
\hline & & Volume & $463[408]$ & 875 [665] & $1,469[1,427]$ & $1,844[1,744]$ & $3,290[3,042]$ & $6,410[5,646]$ \\
\hline & & $\%$ Total & $6.47 \%$ & $5.20 \%$ & $4.63 \%$ & $3.96 \%$ & $3.66 \%$ & $5.16 \%$ \\
\hline & & No. Orders & 507 [483] & $1233[876]$ & $1,902[1,880]$ & $2,005[1,919]$ & $2,613[2,519]$ & $3,170[2,985]$ \\
\hline & & $\%$ Total & $7.54 \%$ & $7.69 \%$ & $7.04 \%$ & $5.62 \%$ & $5.00 \%$ & $5.56 \%$ \\
\hline & \multirow{7}{*}{ Sell } & \multirow{2}{*}{ Value } & $4,879.64$ & $18,070.94$ & $32,237.96$ & $30,461.89$ & $35,162.01$ & $41,749.91$ \\
\hline & & & {$[4,114.49]$} & {$[13,550.84]$} & {$[29,207.90]$} & {$[29,923.92]$} & {$[32,024.78]$} & {$[32,866.11]$} \\
\hline & & $\%$ Total & $3.61 \%$ & $3.16 \%$ & $3.02 \%$ & $2.49 \%$ & $1.88 \%$ & $4.48 \%$ \\
\hline & & Volume & $452[387]$ & 806 [698] & $1,439[1,339]$ & $1,894[1,796]$ & $2,983[2,733]$ & $6,610[5,604]$ \\
\hline & & $\%$ Total & $6.31 \%$ & $4.79 \%$ & $4.53 \%$ & $4.07 \%$ & $3.32 \%$ & $5.32 \%$ \\
\hline & & No. Orders & $511[476]$ & 998 [904] & $1,813[1,756]$ & $2,063[2,003]$ & $2,403[2,262]$ & $3,104[2,824]$ \\
\hline & & $\%$ Total & $7.59 \%$ & $6.23 \%$ & $6.71 \%$ & $5.78 \%$ & $4.60 \%$ & $5.45 \%$ \\
\hline \multirow{6}{*}{ CASE Overall } & \multirow{6}{*}{ Total } & \multirow{2}{*}{ Value } & $135,090.95$ & $571,881.90$ & $1,067,727.79$ & $1,224,555.33$ & $1,869,357.35$ & $931,133.23$ \\
\hline & & & {$[110,482.9]$} & {$[395,704.87]$} & {$[834,410.01]$} & {$[1,020,869.00]$} & {$[1,298,007.47]$} & {$[764,901.48]$} \\
\hline & & \multirow{2}{*}{ Volume } & 7,160 & 16,832 & 31,750 & 46,541 & 89,834 & 124,329 \\
\hline & & & {$[6,498]$} & {$[12,355]$} & {$[28,544]$} & {$[40,479]$} & {$[78,444]$} & {$[104,415]$} \\
\hline & & \multirow{2}{*}{ No. Trades } & 6,728 & 16,031 & 27,007 & 35,702 & 52,255 & 56,999 \\
\hline & & & {$[6,448]$} & {$[12,008]$} & {$[26,717]$} & {$[34,556]$} & {$[50,422]$} & {$[53,853]$} \\
\hline
\end{tabular}

Source: Compiled by author from Cairo and Alexandria Stock Exchange (2009)

Notes: Square brackets indicate Median values 
Table 3 Contrast of market trading and institutions

\begin{tabular}{|c|c|c|c|c|c|c|c|}
\hline Country & Market & $\begin{array}{l}\text { Min No. } \\
\text { Shareholders }\end{array}$ & $\begin{array}{l}\text { Min. Amount } \\
\text { Issued }\end{array}$ & $\begin{array}{l}\text { Min. Amount } \\
\text { Issued (UK£) }\end{array}$ & $\begin{array}{l}\text { No. Shares } \\
\text { Issued }\end{array}$ & Min. Sales & $\begin{array}{l}\text { No. Years } \\
\text { Financial } \\
\text { Statements }\end{array}$ \\
\hline \multirow[t]{3}{*}{ Morocco } & Marché principal & -- -- & MAD 75m & $5.82 \mathrm{~m}$ & 250,000 & No Fixed Limit & 3 \\
\hline & Marché développement & -- -- & MAD 25m & $1.94 \mathrm{~m}$ & 100,000 & $>$ MAD $50 \mathrm{~m}$ & 2 \\
\hline & Marché croissance & ---- & MAD 10m & $0.78 \mathrm{~m}$ & 30,000 & No Fixed Limit & 1 \\
\hline \multirow[t]{4}{*}{ Egypt } & Main Market: Official & 150 & EGP 20m & $2.23 \mathrm{~m}$ & $2,000,000$ & $\begin{array}{l}\text { The net profits before taxes for the last } \\
\text { fiscal year preceding the listing application } \\
\text { should not be less than } 5 \% \text { of the paid-in } \\
\text { capital }\end{array}$ & 3 \\
\hline & Main Market: Unofficial (1) & 50 & EGP $10 \mathrm{~m}$ & $1.12 \mathrm{~m}$ & $1,000,000$ & $\begin{array}{l}\text { The net profits before taxes for the last } \\
\text { fiscal year preceding the listing application } \\
\text { should not be less than } 5 \% \text { of the paid-in } \\
\text { capital }\end{array}$ & 2 \\
\hline & Main Market: Unofficial (2) & $\mathrm{N} / \mathrm{A}$ & EGP 5m & $0.56 \mathrm{~m}$ & 500,000 & $\begin{array}{l}\text { The company should have realized a net } \\
\text { profit that is no less than } 1 \% \text { of the paid-in } \\
\text { capital in the last year preceding the listing } \\
\text { application }\end{array}$ & 1 \\
\hline & Nilex & 25 & EGP 25m & $2.78 \mathrm{~m}$ & 100,000 & No Fixed Limit & 1 \\
\hline \multirow[t]{2}{*}{ Tunisia } & Main Market & 200 & TD $3 \mathrm{~m}$ & $1.39 \mathrm{~m}$ & -- -- & $\begin{array}{l}\text { The last two financial years must have } \\
\text { shown a profit }\end{array}$ & 2 \\
\hline & Alternate Market & $\begin{array}{l}100 \text { (or } 5 \\
\text { institutional } \\
\text { shareholders) }\end{array}$ & $\begin{array}{l}\text { No minimum } \\
\text { amount }\end{array}$ & -- -- & -- -- & The condition of profit is not required & 0 \\
\hline
\end{tabular}

Source: Compiled by author from National stock exchange regulator websites

Notes: (1) The listing of foreign shares in Egypt is undertaken on either of the two unofficial market compartments and not the official (main) compartment.

(2) The Egyptian "Official" compartment is used for listing of major public corporations or divestments of Government shares/ Privatizations

(3) The constituents of the prestigious market barometer CASE70 index are the top 100 stocks less the top 30 stocks that form the top tier CASE30 index

(4) CASE70 constituents are listed on Main Market "Official" compartment

(5) Data is unavailable for Bourse d'Alger (Algeria) 


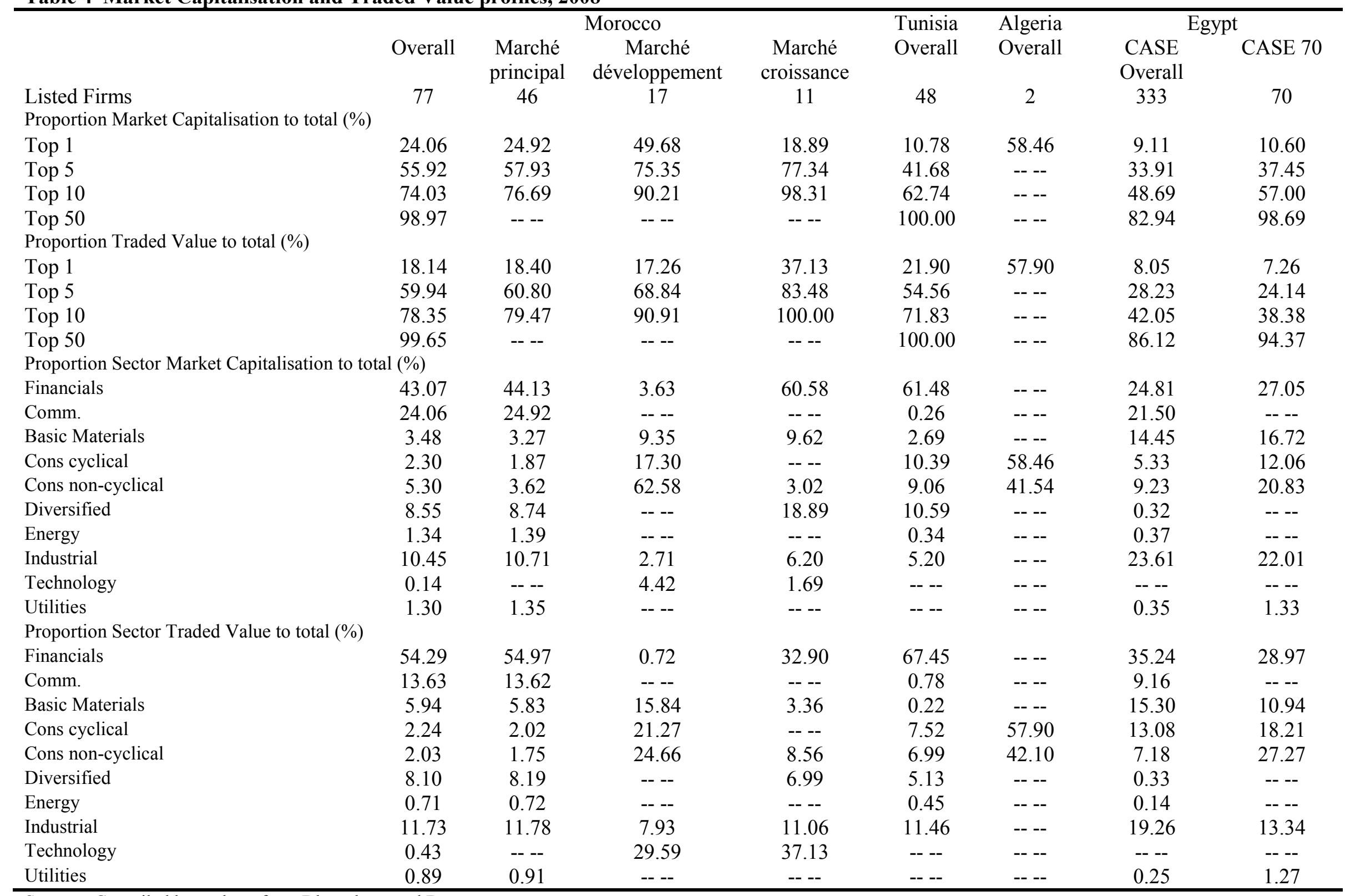




\begin{tabular}{|c|c|c|c|c|c|c|c|c|c|}
\hline & & & & Local market & & & $£$ £UK equi & & \\
\hline Country & Sector & No. Firms & $\begin{array}{c}\text { Zero } \\
\text { Return (\%) }\end{array}$ & Price & $\begin{array}{c}\text { Volume } \\
\text { (thousands) }\end{array}$ & $\begin{array}{c}\text { Market } \\
\text { Capitalization } \\
\text { (millions) }\end{array}$ & Price & $\begin{array}{c}\text { Market } \\
\text { Capitalization } \\
\text { (millions) }\end{array}$ & $\begin{array}{c}\text { Bid-Ask } \\
\text { spread } \\
(\%)\end{array}$ \\
\hline \multirow{2}{*}{ Algeria } & \multirow{2}{*}{ Overall } & \multirow{2}{*}{2} & 95.66 & 420.81 & 4.20 & $3,566.29$ & 3.62 & 30.71 & \\
\hline & & & {$[96.67]$} & {$[408.58]$} & {$[1.82]$} & {$[3,250.00]$} & [3.04] & [24.84] & \\
\hline \multirow{17}{*}{ Morocco } & \multirow{2}{*}{ Basic Materials } & \multirow{2}{*}{11} & 45.81 & 555.22 & 82.64 & $1,357.92$ & 35.49 & 86.96 & 0.0107 \\
\hline & & & [46.02] & {$[513.23]$} & {$[17.26]$} & {$[1,172.88]$} & {$[32.4]$} & {$[71.15]$} & {$[0.0015]$} \\
\hline & \multirow{2}{*}{ Consumer Cyclicals } & \multirow{2}{*}{8} & 60.76 & 331.96 & 77.01 & 456.63 & 21.53 & 30.62 & 0.0130 \\
\hline & & & [69.84] & [225.91] & {$[37.47]$} & {$[177.04]$} & {$[14.06]$} & {$[10.98]$} & {$[0.0003]$} \\
\hline & \multirow{2}{*}{ Consumer Non-Cyclicals } & \multirow{2}{*}{14} & 61.81 & $1,193.94$ & 14.67 & $1,823.88$ & 76.01 & 115.84 & 0.0161 \\
\hline & & & {$[61.96]$} & {$[1,288.2]$} & {$[5.01]$} & {$[1,803.98]$} & [83.11] & [120.27] & {$[0.0005]$} \\
\hline & \multirow{2}{*}{ Diversified } & \multirow{2}{*}{3} & 44.18 & 968.57 & 125.41 & $10,869.06$ & 62.41 & 696.11 & 0.0123 \\
\hline & & & [44.93] & [822.94] & [41.67] & {$[9,855.55]$} & {$[51.31]$} & {$[626.57]$} & {$[0.0001]$} \\
\hline & \multirow{2}{*}{ Financials } & \multirow{2}{*}{20} & 55.16 & 566.82 & $1,536.15$ & $2,235.69$ & 36.45 & 152.79 & 0.0134 \\
\hline & & & [58.24] & [474.17] & {$[175.35]$} & [918.39] & [29.48] & [56.27] & {$[0.0004]$} \\
\hline & \multirow{2}{*}{ Industrial } & \multirow{2}{*}{11} & 37.72 & 758.24 & 55.12 & $4,059.03$ & 48.17 & 260.64 & 0.0084 \\
\hline & & & [38.18] & {$[678.2]$} & [19.63] & {$[3,448.3]$} & {$[42.79]$} & [213.48] & {$[0.0001]$} \\
\hline & \multirow{2}{*}{ Marché principal } & \multirow{2}{*}{47} & 40.13 & 615.96 & 841.75 & $5,133.14$ & 39.42 & 334.80 & 0.0089 \\
\hline & & & [41.05] & {$[544.55]$} & {$[132.65]$} & {$[3,240.20]$} & {$[33.87]$} & [198.93] & {$[0.0008]$} \\
\hline & \multirow{2}{*}{ Marché développement } & \multirow{2}{*}{18} & 60.64 & 886.93 & 15.49 & 682.00 & 56.51 & 43.53 & 0.0158 \\
\hline & & & [63.62] & {$[957.43]$} & {$[3.35]$} & {$[760.84]$} & {$[60.87]$} & [46.33] & {$[0.0015]$} \\
\hline & \multirow{2}{*}{ Marché croissance } & \multirow{2}{*}{11} & 76.34 & 723.88 & 2.94 & 382.44 & 46.27 & 24.23 & 0.0209 \\
\hline \multirow{7}{*}{ Tunisia } & & & {$[82.47]$} & {$[709.54]$} & {$[1.56]$} & [373.37] & [44.11] & [23.66] & {$[0.0000]$} \\
\hline & \multirow{2}{*}{ Overall } & \multirow{2}{*}{73} & 50.21 & 691.24 & 540.06 & $3,393.78$ & 44.18 & 220.96 & 0.0121 \\
\hline & & & [52.61] & {$[665.7]$} & {$[88.4]$} & {$[2,267.84]$} & {$[40.78]$} & [138.26] & {$[0.0013]$} \\
\hline & \multirow{2}{*}{ Basic Materials } & \multirow[b]{2}{*}{3} & 85.79 & 88.90 & 5.51 & 56.10 & 47.29 & 28.23 & 0.0381 \\
\hline & & & [86.02] & [89.67] & [1.38] & [56.06] & [42.92] & [28.59] & {$[0.0376]$} \\
\hline & \multirow{2}{*}{ Communications } & \multirow{2}{*}{1} & 41.67 & 53.65 & 53.68 & 68.97 & 25.38 & 31.65 & 0.0132 \\
\hline & & & [41.94] & [33.08] & [41.48] & [57.68] & {$[15.56]$} & [24.82] & {$[0.0132]$} \\
\hline
\end{tabular}




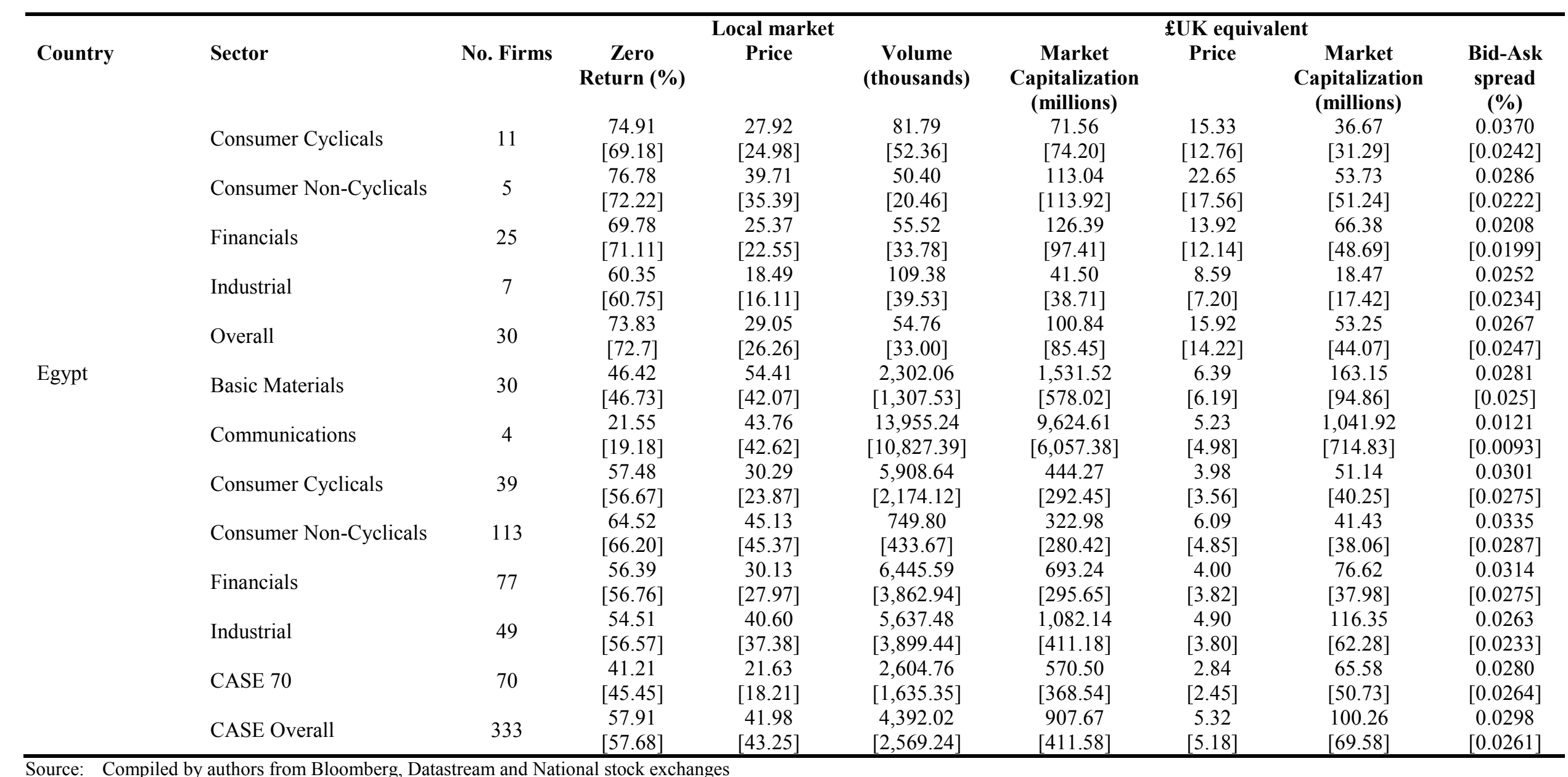


Table 6. Summary statistics for equally weighted monthly excess returns on 9 size-illiquidity portfolios for period 2001 to 2009

\begin{tabular}{|c|c|c|c|c|c|c|c|c|c|}
\hline Portfolio & $\mathbf{S} / \mathbf{L}$ & $\mathbf{S} / \mathbf{M}$ & $\mathbf{S} / \mathbf{H}$ & $\mathbf{M} / \mathbf{L}$ & $\mathbf{M} / \mathbf{M}$ & $\mathbf{M} / \mathbf{H}$ & $\mathbf{B} / \mathbf{L}$ & $\mathbf{B} / \mathbf{M}$ & $\mathbf{B} / \mathbf{H}$ \\
\hline \multicolumn{10}{|c|}{ Panel A: North African market universe } \\
\hline Mean & 0.02588 & 0.02309 & 0.01099 & 0.01985 & 0.02060 & 0.01563 & 0.01530 & 0.01415 & 0.01705 \\
\hline Median & 0.01056 & 0.00666 & 0.00313 & 0.01223 & 0.01204 & 0.00516 & 0.00895 & 0.00851 & 0.00509 \\
\hline Std. Dev. & 0.08602 & 0.09481 & 0.05080 & 0.09264 & 0.09088 & 0.06605 & 0.08501 & 0.05335 & 0.06444 \\
\hline Skewness & 0.417 & 4.603 & 2.220 & 0.954 & 5.832 & 3.382 & 1.365 & 0.519 & 2.594 \\
\hline Excess Kurtosis & 2.702 & 35.633 & 11.817 & 4.840 & 51.602 & 17.868 & 8.634 & 4.832 & 11.676 \\
\hline \multicolumn{10}{|c|}{ Average Number of stocks per size-illiquidity sorted portfolio } \\
\hline Egypt & 23.60 & 12.94 & 15.09 & 23.34 & 7.87 & 10.35 & 22.83 & 8.92 & 9.12 \\
\hline Algeria & 0.00 & 0.00 & 0.21 & 0.00 & 0.00 & 1.35 & 0.00 & 0.00 & 0.42 \\
\hline Tunisia & 1.88 & 8.52 & 5.43 & 2.50 & 8.30 & 3.34 & 0.00 & 6.97 & 5.75 \\
\hline Morocco & 3.01 & 3.20 & 5.11 & 2.12 & 6.50 & 8.46 & 7.09 & 7.52 & 8.92 \\
\hline Overall Mean & 28.50 & 24.66 & 25.84 & 27.96 & 22.66 & 23.50 & 29.92 & 23.42 & 24.21 \\
\hline \multicolumn{10}{|c|}{ Panel B: Morocco market universe } \\
\hline Mean & 0.01198 & 0.00419 & 0.00714 & 0.01026 & 0.01029 & 0.01066 & 0.01131 & 0.00982 & 0.00613 \\
\hline Median & 0.00065 & 0.00276 & 0.00301 & 0.00324 & 0.01161 & 0.00229 & 0.00315 & 0.00597 & 0.00239 \\
\hline Std. Dev. & 0.07714 & 0.06689 & 0.06608 & 0.06204 & 0.07364 & 0.07261 & 0.06407 & 0.07910 & 0.05707 \\
\hline Skewness & 1.624 & 0.937 & 0.103 & 0.339 & 2.655 & 0.776 & 0.076 & 0.690 & 0.331 \\
\hline Excess Kurtosis & 7.772 & 5.326 & 3.812 & 3.507 & 22.168 & 5.561 & 4.054 & 4.011 & 3.781 \\
\hline \multicolumn{10}{|c|}{ Average Number of stocks per size-illiquidity sorted portfolio } \\
\hline Overall Mean & 10.354 & 4.602 & 5.876 & 8.611 & 2.832 & 3.929 & 8.690 & 2.903 & 4.124 \\
\hline \multicolumn{10}{|c|}{ Panel C: Tunisia market universe } \\
\hline Mean & 0.00746 & 0.00655 & 0.01034 & 0.04060 & 0.01432 & 0.00904 & 0.01191 & 0.03833 & 0.04733 \\
\hline Median & -0.00164 & 0.00126 & -0.00590 & 0.00147 & -0.00384 & -0.00009 & 0.00002 & -0.00596 & -0.00054 \\
\hline Std. Dev. & 0.06813 & 0.05506 & 0.08776 & 0.21335 & 0.14126 & 0.06317 & 0.06281 & 0.36153 & 0.30608 \\
\hline Skewness & 1.853 & 0.470 & 4.018 & 6.111 & 6.274 & 4.038 & 2.927 & 8.481 & 7.292 \\
\hline Excess Kurtosis & 11.826 & 7.244 & 28.308 & 42.575 & 54.510 & 33.028 & 19.489 & 80.551 & 59.650 \\
\hline \multicolumn{10}{|c|}{ Average Number of stocks per size-illiquidity sorted portfolio } \\
\hline Overall Mean & 9.389 & 3.619 & 4.619 & 7.558 & 1.885 & 3.044 & 7.646 & 1.973 & 2.973 \\
\hline \multicolumn{10}{|c|}{ Panel D: Egypt market universe } \\
\hline Mean & 0.03223 & 0.03529 & 0.01044 & 0.02289 & 0.01429 & 0.02700 & 0.02008 & 0.01399 & 0.00811 \\
\hline Median & 0.01597 & 0.01361 & 0.00475 & 0.00224 & 0.00396 & 0.00323 & 0.01074 & 0.00368 & -0.00392 \\
\hline Std. Dev. & 0.10521 & 0.12009 & 0.06635 & 0.11284 & 0.10143 & 0.11632 & 0.11206 & 0.09335 & 0.08231 \\
\hline Skewness & 0.653 & 1.886 & 2.449 & 1.376 & 0.652 & 3.543 & 2.133 & 0.635 & 3.084 \\
\hline Excess Kurtosis & 3.060 & 9.874 & 15.675 & 6.885 & 4.582 & 18.590 & 13.645 & 4.606 & 22.073 \\
\hline \multicolumn{10}{|c|}{ Average Number of stocks per size-illiquidity sorted portfolio } \\
\hline Overall Mean & 19.097 & 13.593 & 14.805 & 17.088 & 11.973 & 12.903 & 18.655 & 13.265 & 12.673 \\
\hline
\end{tabular}


Table 7. Summary statistics for individual market and sector portfolios and factors

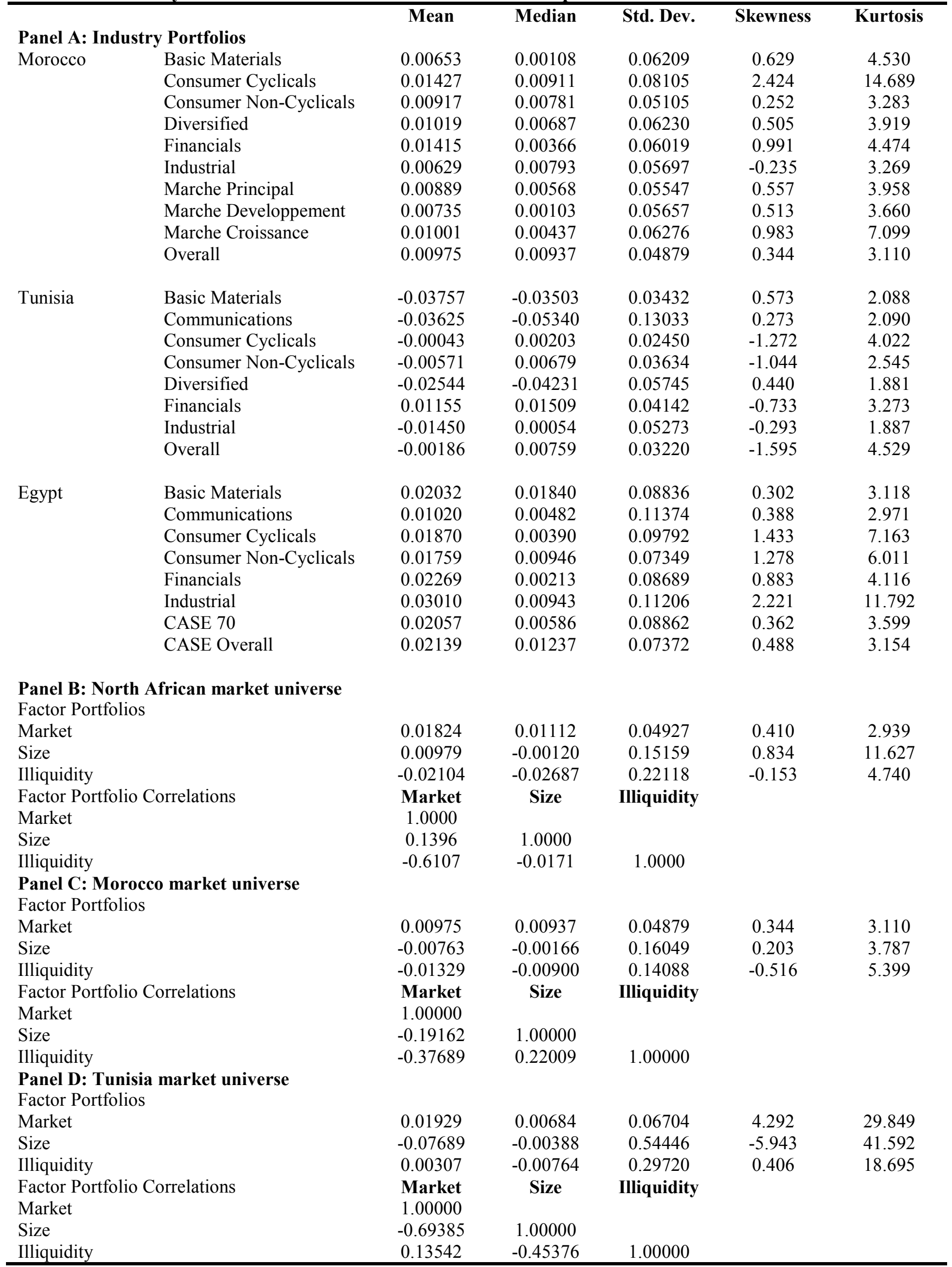




\begin{tabular}{lccccc}
\hline Panel E: Egypt market universe & & & & & \\
Factor Portfolios & 0.02139 & 0.01237 & 0.07372 & 0.488 & 3.154 \\
Market & 0.03210 & 0.00778 & 0.17692 & 0.068 & 5.313 \\
Size & -0.03333 & -0.02315 & 0.25665 & -0.413 & 4.093 \\
Illiquidity & Market & Size & Illiquidity & & \\
Factor Portfolio Correlations & 1.00000 & & & & \\
Market & -0.02095 & 1.00000 & & \\
Size & -0.50680 & 0.31282 & 1.00000 & & \\
Illiquidity & & &
\end{tabular}


Table 8 Time series regressions using equally weighted monthly contemporaneous market excess returns for 9 portfolios formed on size and illiquidity for period: $2000-2008$, for all sample markets.

\begin{tabular}{|c|c|c|c|c|c|c|c|c|c|}
\hline Portfolio & $\mathbf{S} / \mathbf{L}$ & $\mathbf{S} / \mathbf{M}$ & $\mathbf{S} / \mathbf{H}$ & $\mathbf{M} / \mathbf{L}$ & $\mathbf{M} / \mathbf{M}$ & $\mathbf{M} / \mathbf{H}$ & $B / L$ & $\mathbf{B} / \mathbf{M}$ & $\mathbf{B} / \mathbf{H}$ \\
\hline \multicolumn{10}{|c|}{$\begin{array}{l}\text { Panel A: Morocco Market Universe } \\
\text { CAPM-adjusted performance }\end{array}$} \\
\hline$\hat{\alpha}(\%)$ & $\begin{array}{c}-0.000238 \\
{[-0.07]}\end{array}$ & $\begin{array}{c}-0.003685 \\
{[-0.86]}\end{array}$ & $\begin{array}{c}0.002232 \\
{[0.42]}\end{array}$ & $\begin{array}{c}0.000139 \\
{[0.04]}\end{array}$ & $\begin{array}{c}0.000969 \\
{[0.20]}\end{array}$ & $\begin{array}{c}0.001920 \\
{[0.39]}\end{array}$ & $\begin{array}{c}0.000600 \\
{[0.21]}\end{array}$ & $\begin{array}{c}-0.001848 \\
{[-0.39]}\end{array}$ & $\begin{array}{c}-0.002646 \\
{[-0.69]}\end{array}$ \\
\hline \multirow[t]{2}{*}{$\hat{\beta}$} & 1.253432 & 0.808320 & 0.503535 & 1.038871 & 0.955979 & 0.896997 & 1.098721 & 1.197352 & 0.900858 \\
\hline & [9.94] & {$[6.72]$} & {$[3.26]$} & [12.31] & {$[5.00]$} & [5.27] & [13.19] & [10.68] & [11.31] \\
\hline $\operatorname{Adj} R^{2}(1)$ & 0.6250 & 0.3417 & 0.1304 & 0.6643 & 0.3957 & 0.3575 & 0.6972 & 0.5412 & 0.5894 \\
\hline \multicolumn{10}{|c|}{ Three-factor Size and Illiquidity CAPM performance } \\
\hline$\hat{\alpha}$ & $\begin{array}{c}-0.000411 \\
{[-0.15]}\end{array}$ & $\begin{array}{c}-0.003481 \\
{[-0.89]}\end{array}$ & $\begin{array}{l}0.003180 \\
{[0.93]}\end{array}$ & $\begin{array}{l}-0.000306 \\
{[-0.10]}\end{array}$ & $\begin{array}{c}0.000992 \\
{[0.20]}\end{array}$ & $\begin{array}{c}0.002616 \\
{[0.71]}\end{array}$ & $\begin{array}{c}0.000208 \\
{[0.09]}\end{array}$ & $\begin{array}{c}-0.001988 \\
{[-0.58]}\end{array}$ & $\begin{array}{c}-0.002618 \\
{[-0.93]}\end{array}$ \\
\hline$\hat{\beta}$ & $\begin{array}{l}1.188220 \\
{[23.00]}\end{array}$ & $\begin{array}{l}0.894786 \\
{[7.78]}\end{array}$ & $\begin{array}{c}0.893010 \\
{[8.77]}\end{array}$ & $\begin{array}{c}0.856348 \\
{[14.36]}\end{array}$ & $\begin{array}{c}0.962569 \\
{[5.04]}\end{array}$ & $\begin{array}{c}1.178681 \\
{[9.89]}\end{array}$ & $\begin{array}{c}0.935681 \\
{[20.06]}\end{array}$ & $\begin{array}{c}1.133931 \\
{[12.06]}\end{array}$ & $\begin{array}{c}0.907481 \\
{[16.88]}\end{array}$ \\
\hline$\hat{s}$ & $\begin{array}{l}0.176180 \\
{[7.86]}\end{array}$ & $\begin{array}{l}0.133938 \\
{[4.53]}\end{array}$ & $\begin{array}{l}0.158592 \\
{[5.36]}\end{array}$ & $\begin{array}{c}-0.066144 \\
{[-2.93]}\end{array}$ & $\begin{array}{c}-0.102720 \\
{[-2.38]}\end{array}$ & $\begin{array}{c}-0.031551 \\
{[-1.02]}\end{array}$ & $\begin{array}{c}-0.146042 \\
{[-7.83]}\end{array}$ & $\begin{array}{l}-0.222732 \\
{[-10.12]}\end{array}$ & $\begin{array}{l}-0.162781 \\
{[-11.42]}\end{array}$ \\
\hline$\hat{h}$ & $\begin{array}{c}-0.161960 \\
{[-4.05]}\end{array}$ & $\begin{array}{l}0.001868 \\
{[0.03]}\end{array}$ & $\begin{array}{l}0.265992 \\
{[5.30]}\end{array}$ & $\begin{array}{c}-0.129391 \\
{[-3.49]}\end{array}$ & $\begin{array}{c}0.065551 \\
{[1.52]}\end{array}$ & $\begin{array}{l}0.277085 \\
{[6.73]}\end{array}$ & $\begin{array}{c}-0.065213 \\
{[-2.47]}\end{array}$ & $\begin{array}{c}0.070735 \\
{[2.28]}\end{array}$ & $\begin{array}{c}0.100368 \\
{[5.10]}\end{array}$ \\
\hline $\operatorname{Adj} R^{2}(4)$ & 0.7954 & 0.4322 & 0.6112 & 0.7785 & 0.4395 & 0.5939 & 0.8581 & 0.7317 & 0.8089 \\
\hline \multicolumn{10}{|c|}{$\begin{array}{l}\text { Panel B: Tunisia Market Universe } \\
\text { CAPM-adjusted performance }\end{array}$} \\
\hline$\hat{\alpha}(\%)$ & $\begin{array}{c}0.002376 \\
{[0.36]}\end{array}$ & $\begin{array}{c}0.004484 \\
{[0.80]}\end{array}$ & $\begin{array}{c}0.005547 \\
{[0.85]}\end{array}$ & $\begin{array}{l}-0.008030 \\
{[-0.93]}\end{array}$ & $\begin{array}{c}0.006485 \\
{[0.69]}\end{array}$ & $\begin{array}{c}0.006323 \\
{[1.27]}\end{array}$ & $\begin{array}{l}0.006545 \\
{[0.91]}\end{array}$ & $\begin{array}{c}-0.013767 \\
{[-1.24]}\end{array}$ & $\begin{array}{c}-0.015846 \\
{[-0.89]}\end{array}$ \\
\hline$\hat{\beta}$ & $\begin{array}{l}0.263525 \\
{[1.01]}\end{array}$ & $\begin{array}{l}0.107040 \\
{[1.29]}\end{array}$ & $\begin{array}{l}0.248533 \\
{[1.20]}\end{array}$ & $\begin{array}{c}2.520517 \\
{[6.99]}\end{array}$ & $\begin{array}{c}0.405831 \\
{[1.19]}\end{array}$ & $\begin{array}{c}0.140891 \\
{[3.06]}\end{array}$ & $\begin{array}{l}0.278285 \\
{[1.51]}\end{array}$ & $\begin{array}{l}2.700260 \\
{[2.53]}\end{array}$ & $\begin{array}{l}3.274500 \\
{[3.48]}\end{array}$ \\
\hline $\operatorname{Adj} R^{2}(1)$ & 0.0588 & 0.0081 & 0.0273 & 0.6238 & 0.0284 & 0.0135 & 0.0800 & 0.2439 & 0.5099 \\
\hline \multicolumn{10}{|c|}{ Three-factor Size and Illiquidity CAPM performance } \\
\hline$\hat{\alpha}$ & $\begin{array}{c}0.000245 \\
{[0.04]}\end{array}$ & $\begin{array}{l}0.003240 \\
{[0.59]}\end{array}$ & $\begin{array}{c}0.002514 \\
{[0.49]}\end{array}$ & $\begin{array}{l}-0.009488 \\
{[-0.75]}\end{array}$ & $\begin{array}{c}0.004506 \\
{[0.56]}\end{array}$ & $\begin{array}{c}0.006127 \\
{[1.35]}\end{array}$ & $\begin{array}{l}0.005555 \\
{[0.94]}\end{array}$ & $\begin{array}{c}0.005479 \\
{[0.36]}\end{array}$ & $\begin{array}{c}-0.008682 \\
{[-0.83]}\end{array}$ \\
\hline$\hat{\beta}$ & $\begin{array}{c}0.635030 \\
{[2.44]}\end{array}$ & $\begin{array}{c}0.336226 \\
{[2.26]}\end{array}$ & $\begin{array}{c}0.900926 \\
{[1.98]}\end{array}$ & $\begin{array}{c}2.599378 \\
{[3.65]}\end{array}$ & $\begin{array}{c}0.739331 \\
{[1.44]}\end{array}$ & $\begin{array}{c}0.244274 \\
{[1.58]}\end{array}$ & $\begin{array}{c}0.389122 \\
{[2.70]}\end{array}$ & $\begin{array}{c}-0.999132 \\
{[-0.72]}\end{array}$ & $\begin{array}{c}2.480261 \\
{[2.93]}\end{array}$ \\
\hline$\hat{S}$ & $\begin{array}{c}0.065244 \\
{[2.62]}\end{array}$ & $\begin{array}{c}0.041714 \\
{[1.66]}\end{array}$ & $\begin{array}{c}0.129307 \\
{[1.55]}\end{array}$ & $\begin{array}{c}-0.007035 \\
{[-0.08]}\end{array}$ & $\begin{array}{c}0.057180 \\
{[1.47]}\end{array}$ & $\begin{array}{c}0.026396 \\
{[1.02]}\end{array}$ & $\begin{array}{c}0.012100 \\
{[1.18]}\end{array}$ & $\begin{array}{c}-0.690690 \\
{[-2.77]}\end{array}$ & $\begin{array}{c}-0.085270 \\
{[-0.57]}\end{array}$ \\
\hline$\hat{h}$ & $\begin{array}{c}-0.006400 \\
{[-0.08]}\end{array}$ & $\begin{array}{c}0.009794 \\
{[0.55]}\end{array}$ & $\begin{array}{c}0.127056 \\
{[1.36]}\end{array}$ & $\begin{array}{c}-0.197402 \\
{[-1.27]}\end{array}$ & $\begin{array}{c}-0.018784 \\
{[-0.40]}\end{array}$ & $\begin{array}{c}0.075563 \\
{[1.35]}\end{array}$ & $\begin{array}{c}-0.071048 \\
{[-1.67]}\end{array}$ & $\begin{array}{c}-0.321143 \\
{[-1.41]}\end{array}$ & $\begin{array}{c}0.522586 \\
{[3.43]}\end{array}$ \\
\hline $\operatorname{Adj} R^{2}(4)$ & 0.1979 & 0.0672 & 0.2839 & 0.6897 & 0.0444 & 0.0906 & 0.2090 & 0.6738 & 0.8298 \\
\hline
\end{tabular}




\begin{tabular}{|c|c|c|c|c|c|c|c|c|c|}
\hline Portfolio & $\mathbf{S} / \mathbf{L}$ & $\mathbf{S} / \mathbf{M}$ & $\mathbf{S} / \mathbf{H}$ & $\mathbf{M} / \mathbf{L}$ & $\mathbf{M} / \mathbf{M}$ & $\mathbf{M} / \mathbf{H}$ & $\mathrm{B} / \mathrm{L}$ & $\mathbf{B} / \mathbf{M}$ & $\mathrm{B} / \mathrm{H}$ \\
\hline \multicolumn{10}{|c|}{$\begin{array}{l}\text { Panel C: Egypt Market Universe } \\
\text { CAPM-adjusted performance }\end{array}$} \\
\hline$\hat{\alpha}(\%)$ & $\begin{array}{l}0.005756 \\
{[1.13]}\end{array}$ & $\begin{array}{c}0.011905 \\
{[1.73]}\end{array}$ & $\begin{array}{l}0.001633 \\
{[0.24]}\end{array}$ & $\begin{array}{c}-0.005066 \\
{[-1.17]}\end{array}$ & $\begin{array}{c}-0.010831 \\
{[-2.38]}\end{array}$ & $\begin{array}{c}0.010204 \\
{[1.25]}\end{array}$ & $\begin{array}{c}-0.003442 \\
{[-0.54]}\end{array}$ & $\begin{array}{c}-0.007616 \\
{[-1.44]}\end{array}$ & $\begin{array}{c}-0.006500 \\
{[-1.42]}\end{array}$ \\
\hline \multirow{2}{*}{$\hat{\beta}$} & 1.237597 & 1.092954 & 0.411551 & 1.306707 & 1.174292 & 0.785035 & 1.099710 & 1.009823 & 0.682903 \\
\hline & {$[17.45]$} & [5.27] & [5.58] & {$[9.46]$} & {$[12.50]$} & [5.65] & [8.75] & {$[16.83]$} & [5.93] \\
\hline $\operatorname{Adj} R^{2}(1)$ & 0.7496 & 0.4451 & 0.2019 & 0.7262 & 0.7259 & 0.2407 & 0.5191 & 0.6326 & 0.3684 \\
\hline \multicolumn{10}{|c|}{ Three-factor Size and Illiquidity CAPM performance } \\
\hline$\hat{\alpha}$ & $\begin{array}{c}0.001635 \\
{[0.45]}\end{array}$ & $\begin{array}{c}0.000531 \\
{[0.08]}\end{array}$ & $\begin{array}{c}0.000267 \\
{[0.05]}\end{array}$ & $\begin{array}{l}-0.004275 \\
{[-1.08]}\end{array}$ & $\begin{array}{c}-0.010092 \\
{[-2.09]}\end{array}$ & $\begin{array}{c}0.009200 \\
{[1.66]}\end{array}$ & $\begin{array}{c}0.004915 \\
{[0.87]}\end{array}$ & $\begin{array}{c}-0.002670 \\
{[-0.48]}\end{array}$ & $\begin{array}{c}-0.003501 \\
{[-1.06]}\end{array}$ \\
\hline$\hat{\beta}$ & $\begin{array}{l}1.045048 \\
{[8.79]}\end{array}$ & $\begin{array}{l}1.131058 \\
{[7.87]}\end{array}$ & $\begin{array}{c}0.614628 \\
{[5.70]}\end{array}$ & $\begin{array}{c}1.015044 \\
{[11.26]}\end{array}$ & $\begin{array}{c}1.187746 \\
{[11.60]}\end{array}$ & $\begin{array}{c}1.333493 \\
{[5.18]}\end{array}$ & $\begin{array}{c}0.850803 \\
{[9.84]}\end{array}$ & $\begin{array}{c}0.975379 \\
{[13.97]}\end{array}$ & $\begin{array}{c}0.963663 \\
{[4.91]}\end{array}$ \\
\hline$\hat{s}$ & $\begin{array}{c}0.139267 \\
{[3.17]}\end{array}$ & $\begin{array}{c}0.341241 \\
{[4.80]}\end{array}$ & $\begin{array}{c}0.025976 \\
{[0.76]}\end{array}$ & $\begin{array}{c}-0.001874 \\
{[-0.03]}\end{array}$ & $\begin{array}{c}-0.023356 \\
{[-0.85]}\end{array}$ & $\begin{array}{c}-0.011124 \\
{[-0.22]}\end{array}$ & $\begin{array}{c}-0.233999 \\
{[-2.94]}\end{array}$ & $\begin{array}{c}-0.147027 \\
{[-2.81]}\end{array}$ & $\begin{array}{c}-0.111974 \\
{[-3.28]}\end{array}$ \\
\hline$\hat{h}$ & $\begin{array}{c}-0.113094 \\
{[-2.91]}\end{array}$ & $\begin{array}{l}0.011871 \\
{[0.48]}\end{array}$ & $\begin{array}{c}0.114352 \\
{[3.74]}\end{array}$ & $\begin{array}{c}-0.165244 \\
{[-6.53]}\end{array}$ & $\begin{array}{c}0.008291 \\
{[0.25]}\end{array}$ & $\begin{array}{c}0.311151 \\
{[3.41]}\end{array}$ & $\begin{array}{c}-0.134397 \\
{[-4.51]}\end{array}$ & $\begin{array}{c}-0.015331 \\
{[-0.75]}\end{array}$ & $\begin{array}{c}0.162309 \\
{[2.57]}\end{array}$ \\
\hline $\operatorname{Adj} R^{2}(4)$ & 0.8242 & 0.7029 & 0.3606 & 0.8298 & 0.7223 & 0.5798 & 0.7939 & 0.7143 & 0.5363 \\
\hline \multicolumn{10}{|c|}{$\begin{array}{l}\text { Panel D: North African Market Universe } \\
\text { CAPM-adjusted performance }\end{array}$} \\
\hline$\hat{\alpha}(\%)$ & $\begin{array}{c}-0.001378 \\
{[-0.35]}\end{array}$ & $\begin{array}{c}0.002770 \\
{[0.59]}\end{array}$ & $\begin{array}{c}0.002762 \\
{[0.55]}\end{array}$ & $\begin{array}{c}-0.009260 \\
{[-2.17]}\end{array}$ & $\begin{array}{c}0.004777 \\
{[1.04]}\end{array}$ & $\begin{array}{c}0.004738 \\
{[1.03]}\end{array}$ & $\begin{array}{c}-0.008205 \\
{[-1.64]}\end{array}$ & $\begin{array}{c}0.001819 \\
{[0.52]}\end{array}$ & $\begin{array}{c}0.006309 \\
{[0.99]}\end{array}$ \\
\hline$\hat{\beta}$ & $\begin{array}{c}1.494271 \\
{[20.67]}\end{array}$ & $\begin{array}{l}1.113654 \\
{[3.38]}\end{array}$ & $\begin{array}{c}0.450806 \\
{[4.39]}\end{array}$ & $\begin{array}{c}1.595828 \\
{[10.35]}\end{array}$ & $\begin{array}{c}0.867230 \\
{[4.63]}\end{array}$ & $\begin{array}{c}0.597190 \\
{[3.98]}\end{array}$ & $\begin{array}{c}1.288366 \\
{[8.28]}\end{array}$ & $\begin{array}{l}0.667135 \\
{[5.78}\end{array}$ & $\begin{array}{c}0.588817 \\
{[5.25]}\end{array}$ \\
\hline $\operatorname{Adj} R^{2}(1)$ & 0.7299 & 0.3288 & 0.1838 & 0.7177 & 0.2139 & 0.1911 & 0.5534 & -0.0762 & 0.1954 \\
\hline \multicolumn{10}{|c|}{ Three-factor Size and Illiquidity CAPM performance } \\
\hline$\hat{\alpha}$ & $\begin{array}{c}0.001867 \\
{[0.67]}\end{array}$ & $\begin{array}{c}0.001547 \\
{[0.31]}\end{array}$ & $\begin{array}{c}-0.000198 \\
{[-0.05]}\end{array}$ & $\begin{array}{c}-0.003133 \\
{[-1.21]}\end{array}$ & $\begin{array}{c}-5.57 \mathrm{E}-06 \\
{[-0.01]}\end{array}$ & $\begin{array}{c}-0.000686 \\
{[-0.24]}\end{array}$ & $\begin{array}{c}-0.002767 \\
{[-1.15]}\end{array}$ & $\begin{array}{c}0.001819 \\
{[0.52]}\end{array}$ & $\begin{array}{c}0.000508 \\
{[0.15]}\end{array}$ \\
\hline$\hat{\beta}$ & $\begin{array}{c}1.112043 \\
{[11.60]}\end{array}$ & $\begin{array}{c}1.016161 \\
{[4.85]}\end{array}$ & $\begin{array}{c}0.684439 \\
{[4.94]}\end{array}$ & $\begin{array}{c}1.012932 \\
{[9.84]}\end{array}$ & $\begin{array}{l}1.387523 \\
{[2.75]}\end{array}$ & $\begin{array}{l}1.108486 \\
{[3.84]}\end{array}$ & $\begin{array}{c}0.904895 \\
{[7.06]}\end{array}$ & $\begin{array}{l}0.667135 \\
{[5.78]}\end{array}$ & $\begin{array}{l}1.238779 \\
{[5.87]}\end{array}$ \\
\hline$\hat{s}$ & $\begin{array}{c}0.122531 \\
{[1.99]}\end{array}$ & $\begin{array}{c}0.347163 \\
{[3.03]}\end{array}$ & $\begin{array}{c}0.075658 \\
{[2.07]}\end{array}$ & $\begin{array}{c}0.005182 \\
{[0.11]}\end{array}$ & $\begin{array}{c}-0.110409 \\
{[-1.29]}\end{array}$ & $\begin{array}{c}0.003069 \\
{[0.07]}\end{array}$ & $\begin{array}{c}-0.213488 \\
{[-3.61]}\end{array}$ & $\begin{array}{c}-0.076298 \\
{[-2.76]}\end{array}$ & $\begin{array}{c}-0.164682 \\
{[-5.54]}\end{array}$ \\
\hline$\hat{h}$ & $\begin{array}{c}-0.120220 \\
{[-5.32]}\end{array}$ & $\begin{array}{c}0.018819 \\
{[0.73]}\end{array}$ & $\begin{array}{c}0.097065 \\
{[4.15]}\end{array}$ & $\begin{array}{c}-0.211792 \\
{[-11.62]}\end{array}$ & $\begin{array}{c}0.172476 \\
{[1.58]}\end{array}$ & $\begin{array}{c}0.186970 \\
{[2.67]}\end{array}$ & $\begin{array}{c}-0.173306 \\
{[-6.26]}\end{array}$ & $\begin{array}{c}-0.042923 \\
{[-1.42]}\end{array}$ & $\begin{array}{c}0.211270 \\
{[4.21}\end{array}$ \\
\hline Adj $R^{2}(4)$ & 0.8241 & 0.6316 & 0.3486 & 0.8767 & 0.3364 & 0.4295 & 0.8462 & 0.5412 & 0.6313 \\
\hline
\end{tabular}

(1) Numbers in parentheses are t-statistics.

(2) One month T-bill risk free rate for month t, which is taken as the one month UK Gilt rate in this case 


\begin{tabular}{|c|c|c|c|c|c|c|c|c|c|c|c|c|}
\hline & & Finance & Comm. & $\begin{array}{c}\text { Basic } \\
\text { Materials }\end{array}$ & $\begin{array}{l}\text { Cons. } \\
\text { cyclical }\end{array}$ & $\begin{array}{l}\text { Cons. non- } \\
\text { cyclical }\end{array}$ & Diversified & Industrial & $\begin{array}{l}\text { Marche } \\
\text { Principal }\end{array}$ & $\begin{array}{c}\text { Marche } \\
\text { Dev. }\end{array}$ & $\begin{array}{l}\text { Marche } \\
\text { Crois. }\end{array}$ & Overall \\
\hline \multicolumn{13}{|c|}{ Market: North Africa } \\
\hline \multirow[t]{16}{*}{ Morocco } & \multicolumn{12}{|c|}{ Panel A: CAPM-adjusted performance } \\
\hline & \multirow[t]{2}{*}{$\hat{\alpha}(\%)$} & 0.00405 & -0.00059 & -0.00236 & 0.00634 & 0.00471 & 0.00165 & -0.00320 & -0.00041 & 0.00024 & 0.00371 & 0.00137 \\
\hline & & {$[0.84]$} & {$[-0.06]$} & & & & & & & & & \\
\hline & \multirow{2}{*}{$\hat{\beta}$} & 0.55329 & 0.47369 & 0.48772 & 0.43477 & 0.24424 & 0.46817 & 0.52071 & 0.50987 & 0.38945 & 0.34513 & 0.45908 \\
\hline & & {$[5.71]$} & {$[3.43]$} & {$[4.93]$} & {$[3.57]$} & {$[2.22]$} & {$[4.50]$} & {$[5.28]$} & {$[5.92]$} & {$[3.68]$} & {$[3.30]$} & {$[6.30]$} \\
\hline & $\operatorname{Adj} R^{2}(1)$ & 0.1979 & 0.1523 & 0.1421 & 0.0614 & 0.0470 & 0.1292 & 0.1955 & 0.1979 & 0.1070 & 0.0650 & 0.2078 \\
\hline & \multicolumn{12}{|c|}{ Panel B: Three-factor CAPM performance } \\
\hline & \multirow[t]{2}{*}{$\hat{\alpha}$} & 0.00185 & -0.00085 & -0.00275 & 0.00386 & 0.00235 & -0.00016 & -0.00458 & -0.00168 & -0.00242 & 0.00146 & -0.00032 \\
\hline & & {$[0.46]$} & {$[-0.08]$} & {$[-0.46]$} & {$[0.56]$} & {$[0.46]$} & {$[-0.03]$} & {$[-0.93]$} & {$[-0.40]$} & {$[-0.46]$} & {$[0.32]$} & {$[-0.08]$} \\
\hline & \multirow[t]{2}{*}{$\hat{\beta}$} & 0.83253 & 0.52707 & 0.57430 & 0.72874 & 0.52942 & 0.68647 & 0.72707 & 0.70831 & 0.67715 & 0.56826 & 0.68498 \\
\hline & & [4.26] & [2.58] & {$[4.31]$} & [4.62] & {$[2.80]$} & {$[3.56]$} & [5.19] & [4.64] & [3.95] & [3.40] & [4.62] \\
\hline & \multirow[t]{2}{*}{$\hat{S}$} & -0.11567 & -0.04445 & -0.08102 & -0.09730 & -0.10021 & -0.07621 & -0.12345 & -0.12822 & -0.05707 & -0.01690 & -0.10668 \\
\hline & & {$[-2.74]$} & [-1.09] & {$[-2.43]$} & {$[-2.11]$} & {$[-2.58]$} & {$[-1.76]$} & {$[-3.83]$} & {$[-3.45]$} & {$[-1.50]$} & {$[-0.49]$} & {$[-3.22]$} \\
\hline & \multirow[t]{2}{*}{$\hat{h}$} & 0.08373 & 0.00760 & 0.01888 & 0.09198 & 0.08831 & 0.06768 & 0.05592 & 0.05229 & 0.09599 & 0.07873 & 0.06568 \\
\hline & & [1.74] & [0.13] & {$[0.65]$} & {$[2.60]$} & {$[2.26]$} & {$[1.35]$} & {$[1.46$} & [1.19] & [3.22] & [2.65] & [1.78] \\
\hline & $\operatorname{Adj} R^{2}(4)$ & 0.3172 & 0.1330 & 0.1668 & 0.1118 & 0.1971 & 0.1789 & 0.3099 & 0.3247 & 0.1970 & 0.0975 & 0.3473 \\
\hline \multirow[t]{15}{*}{ Tunisia } & \multicolumn{12}{|c|}{ Panel A: CAPM-adjusted performance } \\
\hline & \multirow[t]{2}{*}{$\hat{\alpha}(\%)$} & 0.01649 & 0.00603 & 0.003207 & 0.00843 & 0.00928 & -0.02809 & 0.01325 & -- -- & --- & --- & 0.01243 \\
\hline & & {$[2.21]$} & {$[0.33]$} & {$[0.63]$} & {$[1.00]$} & {$[1.35]$} & {$[-1.15]$} & {$[1.32]$} & & & & {$[2.06]$} \\
\hline & \multirow[t]{2}{*}{$\hat{\beta}$} & 0.41048 & -0.13147 & 0.01266 & 0.37758 & 0.28645 & 0.32112 & 0.63984 & ---- & ---- & ---- & 0.37609 \\
\hline & & {$[1.44]$} & {$[-0.51]$} & {$[0.15]$} & {$[1.28]$} & {$[0.98]$} & {$[1.75]$} & {$[1.32]$} & & & & {$[2.57]$} \\
\hline & $\operatorname{Adj} R^{2}(1)$ & 0.0523 & 0.0019 & 0.0001 & 0.0163 & 0.0130 & 0.0746 & 0.0176 & --- & --- & --- & 0.0680 \\
\hline & \multicolumn{12}{|c|}{ Panel B: Three-factor CAPM performance } \\
\hline & $\hat{\alpha}$ & $\begin{array}{c}0.01160 \\
{[2.72]}\end{array}$ & $\begin{array}{c}0.00998 \\
{[0.56]}\end{array}$ & $\begin{array}{c}0.00148 \\
{[0.31]}\end{array}$ & $\begin{array}{c}0.00244 \\
{[0.43]}\end{array}$ & $\begin{array}{c}0.00866 \\
{[1.22]}\end{array}$ & $\begin{array}{c}0.00165 \\
{[0.29]}\end{array}$ & $\begin{array}{c}0.00510 \\
{[0.51]}\end{array}$ & ---- & ---- & ---- & $\begin{array}{c}0.00783 \\
{[2.38]}\end{array}$ \\
\hline & \multirow[t]{2}{*}{$\hat{\beta}$} & 0.79228 & 0.40641 & 0.19975 & 1.07290 & 0.33380 & 0.10887 & 1.51063 & --- & --- & ---- & 0.81915 \\
\hline & & {$[2.88]$} & {$[-1.36]$} & {$[2.25]$} & {$[1.50]$} & {$[1.27]$} & {$[3.13]$} & {$[1.23]$} & & & & {$[2.22]$} \\
\hline & \multirow[t]{2}{*}{$\hat{s}$} & 0.13272 & -0.16085 & -0.03925 & -0.20919 & 0.01908 & -0.32078 & -0.16207 & ---- & ---- & -- -- & -0.01294 \\
\hline & & [1.29] & {$[-2.48]$} & {$[-1.30]$} & {$[-1.33]$} & {$[0.40]$} & {$[-6.70]$} & {$[-0.72]$} & & & & {$[-0.15]$} \\
\hline & \multirow{2}{*}{$\hat{h}$} & 0.16004 & -0.12547 & 0.06209 & 0.22084 & 0.02025 & -0.06248 & 0.29222 & -- -- & -- -- & -- -- & 0.15957 \\
\hline & & [2.01] & {$[-1.90]$} & {$[2.80]$} & [1.58] & {$[0.64]$} & {$[-4.38]$} & {$[1.16]$} & & & & [1.72] \\
\hline & $\operatorname{Adj} R^{2}(4)$ & 0.2305 & 0.0288 & 0.0413 & 0.1677 & 0.0243 & 0.9029 & 0.0815 & -- -- & -- -- & -- -- & 0.2282 \\
\hline
\end{tabular}




\begin{tabular}{|c|c|c|c|c|c|c|c|c|c|c|c|c|}
\hline \multirow{15}{*}{ Egypt } & & Finance & Comm. & $\begin{array}{c}\text { Basic } \\
\text { Materials }\end{array}$ & $\begin{array}{c}\text { Cons. } \\
\text { cyclical }\end{array}$ & $\begin{array}{l}\text { Cons. non- } \\
\text { cyclical }\end{array}$ & Diversified & Industrial & & & CASE 70 & Overall \\
\hline & \multicolumn{12}{|c|}{ Panel A: CAPM-adjusted performance } \\
\hline & $\hat{\alpha}(\%)$ & $\begin{array}{c}-0.00522 \\
{[-1.41]}\end{array}$ & $\begin{array}{c}-0.01153 \\
{[-1.01}\end{array}$ & $\begin{array}{c}-0.00600 \\
{[-1.00]}\end{array}$ & $\begin{array}{c}-0.00787 \\
{[-1.45]}\end{array}$ & $\begin{array}{c}-0.00345 \\
{[-0.67]}\end{array}$ & $\begin{array}{c}-0.01167 \\
{[-0.56]}\end{array}$ & $\begin{array}{c}0.00076 \\
{[0.15]}\end{array}$ & ---- & ---- & $\begin{array}{c}-0.00785 \\
{[-1.74]}\end{array}$ & $\begin{array}{c}-0.00434 \\
{[-1.62]}\end{array}$ \\
\hline & \multirow[t]{2}{*}{$\hat{\beta}$} & 1.52980 & 1.19110 & 1.44304 & 1.45645 & 1.15372 & 2.09557 & 1.60808 & \multirow[t]{2}{*}{----} & \multirow[t]{2}{*}{----} & 1.55849 & 1.41079 \\
\hline & & {$[11.91]$} & {$[5.07]$} & {$[13.23]$} & {$[11.96]$} & {$[11.01]$} & [1.89] & {$[8.05]$} & & & {$[17.68]$} & {$[29.62]$} \\
\hline & $\operatorname{Adj} R^{2}(1)$ & 0.7501 & 0.2595 & 0.6442 & 0.5327 & 0.5945 & 0.1242 & 0.4952 & --- & ---- & 0.7484 & 0.8879 \\
\hline & \multicolumn{12}{|c|}{ Panel B: Three-factor CAPM performance } \\
\hline & $\hat{\alpha}$ & $\begin{array}{c}-0.00193 \\
{[-0.51]}\end{array}$ & $\begin{array}{c}-0.00733 \\
{[-0.60]}\end{array}$ & $\begin{array}{c}-0.00251 \\
{[-0.50]}\end{array}$ & $\begin{array}{c}-0.00606 \\
{[-1.28]}\end{array}$ & $\begin{array}{c}-0.00334 \\
{[-0.81]}\end{array}$ & $\begin{array}{c}-0.00268 \\
{[-0.11]}\end{array}$ & $\begin{array}{c}0.00316 \\
{[0.63]}\end{array}$ & ---- & -- -- & $\begin{array}{c}-0.00434 \\
{[-1.23]}\end{array}$ & $\begin{array}{c}-0.00213 \\
{[-1.12]}\end{array}$ \\
\hline & \multirow[t]{2}{*}{$\hat{\beta}$} & 1.18178 & 0.79985 & 1.07510 & 1.28513 & 1.06984 & 1.82907 & 1.41053 & \multirow[t]{2}{*}{-- -- } & \multirow[t]{2}{*}{----} & 1.21108 & 1.17286 \\
\hline & & {$[10.87$} & {$[2.60]$} & [7.83] & [4.55] & {$[5.77]$} & [1.43] & [4.14] & & & [11.99] & [13.83] \\
\hline & \multirow[t]{2}{*}{$\hat{s}$} & 0.06055 & -0.00920 & 0.06170 & 0.00011 & 0.11873 & -0.54191 & -0.04802 & \multirow[t]{2}{*}{----} & \multirow[t]{2}{*}{---} & 0.02414 & 0.04673 \\
\hline & & {$[1.53]$} & {$[-0.12]$} & {$[1.20]$} & {$[0.01$} & [4.12] & {$[-1.23]$} & {$[-0.36]$} & & & {$[0.49]$} & {$[2.31]$} \\
\hline & \multirow{2}{*}{$\hat{h}$} & -0.11745 & -0.14414 & -0.12453 & -0.06247 & -0.01199 & -0.22265 & -0.07957 & \multirow[t]{2}{*}{-- -- } & \multirow[t]{2}{*}{-- -- } & -0.12292 & -0.07946 \\
\hline & & {$[-5.17]$} & {$[-2.51]$} & {$[-4.88]$} & {$[-0.85]$} & {$[-0.29]$} & {$[-1.60]$} & {$[-1.34]$} & & & {$[-5.37]$} & {$[-3.89]$} \\
\hline & Adj $R^{2}(4)$ & 0.8099 & 0.2972 & 0.7070 & 0.5369 & 0.6471 & 0.2158 & 0.5076 & -- -- & ---- & 0.8044 & 0.9286 \\
\hline \multirow[t]{10}{*}{ Algeria } & \multicolumn{12}{|c|}{ Panel A: CAPM-adjusted performance } \\
\hline & $\hat{\alpha}(\%)$ & --- & ---- & --- & $\begin{array}{c}1.33 \mathrm{E}-05 \\
{[0.01}\end{array}$ & $\begin{array}{c}-0.01112 \\
{[-1.93]}\end{array}$ & ---- & -- -- & ---- & --- & ---- & $\begin{array}{c}-0.00516 \\
{[-0.88]}\end{array}$ \\
\hline & $\hat{\beta}$ & ---- & ---- & ---- & $\begin{array}{c}-0.03115 \\
{[-0.24}\end{array}$ & $\begin{array}{c}0.19233 \\
{[1.65]}\end{array}$ & ---- & ---- & ---- & ---- & ---- & $\begin{array}{c}0.07788 \\
{[0.68]}\end{array}$ \\
\hline & $\operatorname{Adj} R^{2}(1)$ & --- & -- -- & --- & 0.0007 & 0.0197 & --- & ---- & --- & --- & --- & 0.0058 \\
\hline & \multicolumn{12}{|c|}{ Panel B: Three-factor CAPM performance } \\
\hline & $\hat{\alpha}$ & ---- & -- -- & -- -- & $\begin{array}{c}-0.00299 \\
{[-0.48]}\end{array}$ & $\begin{array}{c}-0.01327 \\
{[-2.41}\end{array}$ & -- -- & -- -- & -- -- & -- -- & -- -- & $\begin{array}{c}-0.00761 \\
{[-1.43]}\end{array}$ \\
\hline & $\hat{\beta}$ & -- -- & --- & -- -- & $\begin{array}{c}0.23866 \\
{[1.02]}\end{array}$ & $\begin{array}{c}0.39643 \\
{[1.84]}\end{array}$ & --- & --- & ---- & -- -- & --- & $\begin{array}{c}0.31017 \\
{[1.44]}\end{array}$ \\
\hline & $\hat{s}$ & ---- & --- & -- -- & $\begin{array}{c}-0.00160 \\
{[-0.05]}\end{array}$ & $\begin{array}{c}-0.00187 \\
{[-0.07]}\end{array}$ & --- & ---- & ---- & ---- & ---- & $\begin{array}{c}-0.00071 \\
{[-0.02]}\end{array}$ \\
\hline & $\hat{h}$ & ---- & ---- & ---- & $\begin{array}{c}0.09762 \\
{[2.01]}\end{array}$ & $\begin{array}{c}0.07414 \\
{[1.70]}\end{array}$ & ---- & ---- & ---- & -- -- & -- -- & $\begin{array}{c}0.08461 \\
{[1.89]}\end{array}$ \\
\hline & Adj $R^{2}(4)$ & -- -- & -- -- & -- -- & 0.0634 & 0.0566 & -- -- & -- -- & -- -- & -- -- & -- -- & 0.0681 \\
\hline
\end{tabular}




\section{Finance Comm.}

Market: Morocco

Panel A: CAPM-adjusted performance

0.00473

$\begin{array}{lcc}\hat{\alpha}(\%) & {[1.55]} & {[0.56]} \\ \hat{\beta} & 1.13842 & 0.62617 \\ \text { Adj R }^{2}(1) & {[18.73]} & {[3.52]} \\ \text { Pand } & 0.8501 & 0.2093\end{array}$

Panel B: Three-factor CAPM performance

$\hat{\beta}$
$\hat{s}$
$\hat{h}$

arket: Tunisia

Panel A: CAPM-adjusted performance

$\begin{array}{ll}0.00676 & -0.00283 \\ {[1.84]} & {[-0.18]}\end{array}$

$\hat{\beta}$

Adj R ${ }^{2}(1)$

$0.89250 \quad 0.33526$

[2.99]

0.5281

0.33526
$[1.03]$

[1.03]

performance

$\hat{\alpha}$

$\hat{\beta}$

$\hat{S}$

$\hat{h}$

Adj R ${ }^{2}$ (4)

$[-0.78]$
0.0327
Basic

Materials

$-0.00308$

[-0.93]

0.98691

[8.81]

0.5977

$-0.00331$

[-1.13]

0.89627

[8.60]

0.05120

$[1.31$

$-0.11293$

[-2.14]

0.6552

Cons.

cyclical

0.00364

[0.85]

1.09094

[8.62]

0.4261

0.00366

[0.86]

1.10326

[10.07

0.09836

[2.14]

$-0.04565$

[-0.72]

0.4539

0.00027

[0.06]

0.16396

[3.13]

0.0484

0.00061

$[0.14]$

0.10759

[0.85]

$-0.00964$

[-0.60]

0.00334

$[0.16]$
0.0401

$\begin{array}{cc}-0.00937 & 0.00941 \\ {[-2.08]} & {[1.16]} \\ 1.28042 & 0.26415 \\ {[3.35]} & {[1.27]} \\ 0.5309 & 0.0257 \\ & \\ -0.00857 & 0.00636 \\ {[-1.91]} & {[0.93]} \\ 1.17722 & 0.89071 \\ {[2.71]} & {[1.73]} \\ -0.01367 & 0.12126 \\ {[-0.33]} & {[1.31]} \\ 0.04351 & 0.09463 \\ {[0.85]} & {[0.89]} \\ 0.5419 & 0.1996\end{array}$

0.5419

0.1996
Cons. non-
cyclical

0.00142
$[0.42]$
0.79509
$[8.24]$
0.5734

0.00161
$[0.62]$
0.86834
$[13.68]$
-0.08390
$[-3.60]$
0.11590
$[4.77]$
0.6990

0.00152
$[0.45]$
0.88976
$[7.99]$
0.4808

0.00171
$[0.52]$
0.96724
$[9.08]$
-0.03899
$[-1.18]$
0.09377
$[1.97]$
0.5144

-0.00311
$[-1.09]$
0.96558
$[15.36]$
0.6807

-0.00322
$[-1.23]$
0.91841
$[14.91]$
-0.08282
$[-4.30]$
0.00462
$[0.17]$
0.7280

$-0.02327$

$$
\text { [-1.32] }
$$

1.16206

[2.31]

0.3419

$-0.00994$

[-0.56]

2.56511

[2.73]

0.07969

[0.47]

0.57257

$[1.36]$
0.2296

Industrial

$-0.01665$

[-1.57]

2.15534

[3.53]

0.5516

$-0.01593$

[-1.52]

2.10411

[2.63]

-0.0002
$[-0.01$

0.08334

$[0.73]$
0.5599
Marche

Principal

Dev.

$\begin{array}{ccc}-0.00162 & -0.00127 & 0.00317 \\ {[-1.30]} & {[-0.47]} & {[0.96]} \\ 1.07830 & 0.88508 & 0.70207 \\ {[19.81]} & {[10.75]} & {[4.57]} \\ 0.8985 & 0.5789 & 0.2914 \\ & & \\ -0.00187 & -0.00089 & 0.00380 \\ {[-1.93]} & {[-0.38]} & {[1.26]} \\ 0.97412 & 1.04036 & 0.96418 \\ {[31.52]} & {[14.09]} & {[8.60]} \\ -0.04206 & 0.06477 & 0.12165 \\ {[-3.15]} & {[2.02]} & {[3.47]} \\ -0.07135 & 0.10515 & 0.17036 \\ {[-3.95]} & {[2.46]} & {[3.37]} \\ 0.9470 & 0.6797 & 0.5393\end{array}$

Crois.

0.6797

0.5393

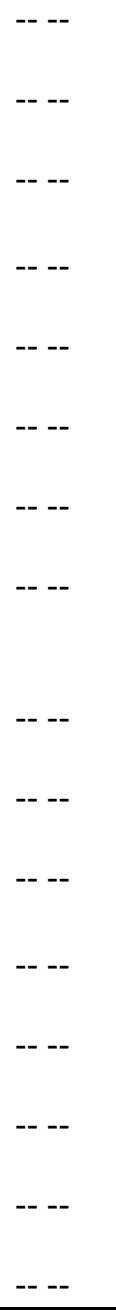




\begin{tabular}{|c|c|c|c|c|c|c|c|c|c|c|c|}
\hline & Finance & Comm. & $\begin{array}{l}\text { Basic } \\
\text { Materials }\end{array}$ & $\begin{array}{l}\text { Cons. } \\
\text { cyclical }\end{array}$ & $\begin{array}{l}\text { Cons. non- } \\
\text { cyclical }\end{array}$ & Diversified & Industrial & & & CASE 70 & Overall \\
\hline \multicolumn{12}{|l|}{ Market: Egypt } \\
\hline \multicolumn{12}{|c|}{ Panel A: CAPM-adjusted performance } \\
\hline$\hat{\alpha}(\%)$ & $\begin{array}{c}-0.00018 \\
{[-0.04]}\end{array}$ & $\begin{array}{c}-0.00693 \\
{[-0.61}\end{array}$ & $\begin{array}{c}-0.00225 \\
{[-0.50]}\end{array}$ & $\begin{array}{c}-0.00370 \\
{[-0.82}\end{array}$ & $\begin{array}{c}0.00012 \\
{[0.03]}\end{array}$ & $\begin{array}{c}0.00245 \\
{[0.13]}\end{array}$ & $\begin{array}{c}0.00586 \\
{[1.37]}\end{array}$ & -- -- & -- -- & $\begin{array}{c}-0.00309 \\
{[-0.88]}\end{array}$ & -- -- \\
\hline$\hat{\beta}$ & 1.06922 & 0.80091 & 1.05563 & 1.04735 & 0.81647 & 1.38784 & 1.13274 & ---- & ---- & 1.10620 & ---- \\
\hline & {$[14.34]$} & {$[5.24]$} & {$[15.81$} & {$[18.06]$} & {$[13.00]$} & {$[2.21$} & {$[8.67]$} & & & {$[19.76]$} & \\
\hline $\operatorname{Adj} R^{2}(1)$ & 0.8212 & 0.2628 & 0.7736 & 0.6182 & 0.6677 & 0.1268 & 0.5512 & ---- & ---- & 0.8453 & ---- \\
\hline \multicolumn{12}{|c|}{ Panel B: Three-factor CAPM performance } \\
\hline$\hat{\alpha}$ & $\begin{array}{c}-0.00079 \\
{[-0.19]}\end{array}$ & $\begin{array}{c}-0.00568 \\
{[-0.48]}\end{array}$ & $\begin{array}{c}-0.00299 \\
{[-0.62]}\end{array}$ & $\begin{array}{c}-0.00223 \\
{[-0.43]}\end{array}$ & $\begin{array}{c}-0.00199 \\
{[-0.57]}\end{array}$ & $\begin{array}{c}0.01008 \\
{[0.51}\end{array}$ & $\begin{array}{c}0.00928 \\
{[1.44]}\end{array}$ & -- -- & -- -- & $\begin{array}{c}-0.00295 \\
{[-0.85]}\end{array}$ & -- -- \\
\hline$\hat{\beta}$ & $\begin{array}{l}0.99832 \\
{[14.01]}\end{array}$ & $\begin{array}{c}0.60285 \\
{[2.96]}\end{array}$ & $\begin{array}{l}1.01316 \\
{[12.38]}\end{array}$ & $\begin{array}{c}1.12031 \\
{[6.95]}\end{array}$ & $\begin{array}{c}0.90337 \\
{[9.11]}\end{array}$ & $\begin{array}{c}1.27925 \\
{[1.99]}\end{array}$ & $\begin{array}{c}1.12945 \\
{[6.22]}\end{array}$ & -- -- & ---- & $\begin{array}{l}1.02471 \\
{[18.42]}\end{array}$ & ---- \\
\hline$\hat{s}$ & $\begin{array}{c}0.02379 \\
{[0.82]}\end{array}$ & $\begin{array}{c}-0.02290 \\
{[-0.33]}\end{array}$ & $\begin{array}{c}0.02545 \\
{[0.72]}\end{array}$ & $\begin{array}{c}-0.05007 \\
{[-0.93]}\end{array}$ & $\begin{array}{c}0.05764 \\
{[2.58]}\end{array}$ & $\begin{array}{c}-0.19218 \\
{[-1.14]}\end{array}$ & $\begin{array}{c}-0.10302 \\
{[-1.03]}\end{array}$ & -- -- & ---- & $\begin{array}{c}0.00199 \\
{[0.05]}\end{array}$ & ---- \\
\hline$\hat{h}$ & $\begin{array}{c}-0.04086 \\
{[-2.42]}\end{array}$ & $\begin{array}{c}-0.11159 \\
{[-1.88}\end{array}$ & $\begin{array}{c}-0.02479 \\
{[-1.11}\end{array}$ & $\begin{array}{c}0.04278 \\
{[0.61]}\end{array}$ & $\begin{array}{c}0.04760 \\
{[1.46]}\end{array}$ & $\begin{array}{c}-0.06962 \\
{[-0.78]}\end{array}$ & $\begin{array}{c}0.00106 \\
{[0.02]}\end{array}$ & ---- & -- -- & $\begin{array}{c}-0.04624 \\
{[-2.66]}\end{array}$ & ---- \\
\hline $\operatorname{Adj} R^{2}(4)$ & 0.8278 & 0.3046 & 0.7738 & 0.6229 & 0.7169 & 0.1275 & 0.5699 & -- -- & ---- & 0.8559 & -- -- \\
\hline
\end{tabular}

(1) The risk free rate is the three month UK treasury/ Gilt rate adjusted for monthly values.

(2) Numbers in parentheses are Newey-West HAC covariance adjusted t-statistics. 
Table 10 Time varying CAPM model parameters for North African Market Universe

\begin{tabular}{|c|c|c|c|c|c|c|c|c|c|c|}
\hline Country & & $\begin{array}{l}\text { Overall } \\
\text { Mean }\end{array}$ & Overall High/ low & 2003 & 2004 & 2005 & 2006 & 2007 & 2008 & $\begin{array}{c}\text { Convergence } \\
\text { (Iterations) }\end{array}$ \\
\hline \multirow[t]{4}{*}{ Algeria } & Constant & -0.00465 & $0.073 /-0.089$ & 0.00121 & -0.0069 & 0.00032 & 0.03804 & 0.01851 & -0.02615 & \multirow[t]{4}{*}{37} \\
\hline & Market Beta & 0.12411 & $2.986 /-1.008$ & 0.28756 & 0.26271 & -0.01879 & -0.70602 & -0.4719 & 1.42294 & \\
\hline & Size Beta & -- -- & -- -- & ---- & -- -- & -- -- & -- -- & --- & -- -- & \\
\hline & Illiquidity Beta & 0.07491 & $0.791 /-0.128$ & 0.01955 & 0.13585 & -0.02798 & -0.01132 & -0.03751 & 0.43333 & \\
\hline \multirow{4}{*}{$\begin{array}{l}\text { Algeria Consumer } \\
\text { Non-Cyclicals }\end{array}$} & Constant & 0.00274 & $0.141 /-0.054$ & -0.00229 & 0.00435 & 0.00310 & 0.06109 & 0.0358 & -0.01164 & \multirow[t]{4}{*}{18} \\
\hline & Market Beta & -0.25685 & $2.798 /-1.843$ & -0.38581 & 0.01247 & 0.05478 & -1.18723 & -0.69527 & 1.47465 & \\
\hline & Size Beta & -- -- & -- -- & -- -- & -- -- & -- -- & -- -- & -- -- & -- -- & \\
\hline & Illiquidity Beta & 0.09494 & $0.752 /-0.280$ & 0.04976 & 0.16199 & -0.01309 & -0.06225 & -0.03357 & 0.41433 & \\
\hline \multirow{4}{*}{$\begin{array}{l}\text { Algeria Consumer } \\
\text { Cyclicals }\end{array}$} & Constant & -0.01235 & $0.085 /-0.132$ & -0.00127 & -0.0201 & -0.00416 & 0.01371 & -0.00314 & -0.02216 & \multirow[t]{4}{*}{30} \\
\hline & Market Beta & 0.39869 & $2.721 /-0.434$ & 0.99922 & 0.46299 & $-9.6 \mathrm{E}-05$ & -0.22629 & -0.17188 & 1.17683 & \\
\hline & Size Beta & -- -- & -- -- & -- -- & -- -- & -- -- & -- -- & -- -- & -- -- & \\
\hline & Illiquidity Beta & 0.05096 & $0.787 /-0.083$ & -0.03109 & 0.09965 & -0.02493 & 0.04795 & -0.03051 & 0.43607 & \\
\hline \multirow{4}{*}{$\begin{array}{l}\text { Morocco Basic } \\
\text { Materials }\end{array}$} & Constant & 0.00226 & $0.152 /-0.103$ & 0.03369 & -0.02883 & 0.00761 & -0.00954 & 0.00625 & -0.02761 & \multirow[t]{4}{*}{26} \\
\hline & Market Beta & 1.00949 & $2.617 /-1.165$ & 0.38619 & 0.74284 & 1.39404 & 0.32976 & 0.21321 & 0.78274 & \\
\hline & Size Beta & -0.16504 & $0.031 /-0.297$ & -0.29203 & -0.22744 & -0.17277 & -0.06806 & -0.02208 & -0.02332 & \\
\hline & Illiquidity Beta & 0.09795 & $0.108 /-0.052$ & 0.08714 & 0.02003 & 0.04393 & 0.00511 & 0.02654 & 0.08547 & \\
\hline \multirow{4}{*}{$\begin{array}{l}\text { Morocco } \\
\text { Consumer } \\
\text { Cyclicals }\end{array}$} & Constant & -0.00929 & $0.099 /-0.083$ & 0.02724 & 0.02908 & -0.04432 & -0.03447 & 0.00283 & -0.03051 & \multirow[t]{4}{*}{28} \\
\hline & Market Beta & 1.04885 & $3.569 /-1.152$ & 0.48149 & 0.15165 & 2.36060 & 2.56335 & 1.22134 & 0.46235 & \\
\hline & Size Beta & -0.14075 & $0.588 /-0.731$ & -0.34471 & -0.03829 & -0.11209 & 0.01664 & -0.225 & 0.13381 & \\
\hline & Illiquidity Beta & 0.12540 & $0.942 /-0.503$ & 0.13885 & 0.01535 & 0.32207 & 0.35737 & -0.11417 & 0.04311 & \\
\hline \multirow{4}{*}{$\begin{array}{l}\text { Morocco } \\
\text { Consumer } \\
\text { Cyclicals }\end{array}$} & Constant & 0.01055 & $0.115 /-0.101$ & 0.02738 & -0.00369 & 0.00525 & 0.01274 & 0.03307 & 0.01595 & \multirow[t]{4}{*}{13} \\
\hline & Market Beta & 0.17729 & $0.713 /-0.264$ & 0.43029 & 0.42777 & 0.19861 & -0.12318 & -0.09094 & 0.14503 & \\
\hline & Size Beta & -0.20709 & $-0.069 /-0.282$ & -0.29513 & -0.25048 & -0.25652 & -0.12478 & -0.08711 & -0.0787 & \\
\hline & Illiquidity Beta & -- -- & -- -- & -- -- & -- -- & -- -- & -- -- & -- -- & -- -- & \\
\hline \multirow{4}{*}{$\begin{array}{l}\text { Morocco } \\
\text { Diversified }\end{array}$} & Constant & 0.00800 & $0.128 /-0.127$ & 0.02600 & 0.00343 & 0.03852 & -0.00403 & 0.02286 & 0.00230 & \multirow[t]{4}{*}{23} \\
\hline & Market Beta & 0.61916 & $0.890 /-0.153$ & 0.95767 & 0.30872 & 0.23951 & 0.40417 & 0.45216 & 0.53526 & \\
\hline & Size Beta & -0.03842 & $0.453 /-0.243$ & -0.00887 & 0.10077 & 0.24922 & -0.01705 & 0.02152 & -0.03975 & \\
\hline & Illiquidity Beta & 0.05722 & $0.180 /-0.116$ & 0.07154 & -0.03904 & 0.11493 & -0.03523 & 0.06717 & 0.09653 & \\
\hline
\end{tabular}




\begin{tabular}{|c|c|c|c|c|c|c|c|c|c|c|}
\hline Country & & $\begin{array}{l}\text { Overall } \\
\text { Mean }\end{array}$ & Overall High/ low & 2003 & 2004 & 2005 & 2006 & 2007 & 2008 & $\begin{array}{c}\text { Convergence } \\
\text { (Iterations) }\end{array}$ \\
\hline Morocco & Constant & 0.00849 & $0.071 /-0.047$ & 0.00608 & -0.00227 & 0.02513 & 0.00252 & 0.00998 & 0.00165 & 14 \\
\hline \multirow[t]{3}{*}{ Financials } & Market Beta & 1.21560 & $3.191 /-0.747$ & 1.84313 & 0.72811 & 0.90465 & 1.43232 & 0.56904 & 0.56363 & \\
\hline & Size Beta & -- -- & -- -- & -- -- & -- -- & -- -- & -- -- & -- -- & -- -- & \\
\hline & Illiquidity Beta & 0.15202 & $0.198 / 0.029$ & 0.19600 & 0.14267 & 0.15496 & 0.09820 & 0.05866 & 0.04792 & \\
\hline Morocco & Constant & -0.00557 & $0.085 /-0.125$ & 0.02581 & -0.01572 & 0.01033 & -0.01771 & -0.0157 & -0.03371 & 43 \\
\hline \multirow[t]{3}{*}{ Industrials } & Market Beta & 0.81523 & $1.143 / 0.420$ & 0.53638 & 0.68532 & 1.01583 & 1.02918 & 1.06541 & 1.10006 & \\
\hline & Size Beta & -0.16448 & $0.121 /-0.244$ & -0.13054 & -0.01625 & -0.12491 & -0.13699 & -0.08297 & -0.09909 & \\
\hline & Illiquidity Beta & 0.04422 & $0.395 /-0.166$ & 0.09522 & -0.05773 & 0.25913 & 0.01187 & 0.11789 & 0.06161 & \\
\hline Morocco Marche & Constant & 0.00061 & $0.089 /-0.114$ & 0.01690 & -0.00991 & 0.00780 & 0.00879 & -0.01105 & -0.0116 & 25 \\
\hline \multirow[t]{3}{*}{ Principal } & Market Beta & 1.02999 & $1.386 / 0.654$ & 1.3730 & 1.10136 & 1.15225 & 0.98382 & 0.84701 & 0.72601 & \\
\hline & Size Beta & -0.20074 & $0.626 /-0.615$ & -0.5285 & 0.21497 & -0.26196 & -0.11028 & -0.12137 & -0.0533 & \\
\hline & Illiquidity Beta & 0.09981 & $0.341 /-0.084$ & 0.12034 & 0.04806 & 0.20302 & 0.05192 & 0.10338 & 0.06638 & \\
\hline Morocco Marche & Constant & 0.00113 & $0.098 /-0.104$ & 0.04898 & -0.01199 & 0.00491 & -0.01198 & 0.01297 & -0.00815 & 17 \\
\hline \multirow[t]{3}{*}{ Developpement } & Market Beta & 0.82429 & $2.067 /-0.149$ & 0.43179 & 1.05298 & 1.77275 & 0.73126 & 0.25003 & 0.37256 & \\
\hline & Size Beta & -- -- & -- -- & -- -- & -- -- & -- -- & -- -- & -- -- & ---- & \\
\hline & Illiquidity Beta & 0.14729 & $0.694 /-0.131$ & 0.13774 & 0.13901 & 0.22478 & 0.09708 & 0.17078 & 0.06042 & \\
\hline Morocco Marche & Constant & 0.01519 & $0.132 /-0.125$ & 0.02693 & 0.01755 & 0.05335 & -0.03047 & 0.01841 & 0.00959 & 24 \\
\hline \multirow[t]{3}{*}{ Croissance } & Market Beta & 0.92423 & $2.313 /-0.864$ & 0.06697 & -0.25662 & -0.35265 & 1.00127 & 0.52294 & 0.27663 & \\
\hline & Size Beta & 0.03786 & $0.252 /-0.101$ & 0.15428 & 0.12126 & 0.16695 & 0.10911 & 0.01829 & -0.05911 & \\
\hline & Illiquidity Beta & 0.13295 & $0.426 /-0.119$ & 0.01993 & -0.0534 & 0.04757 & 0.20241 & 0.09582 & -0.00473 & \\
\hline \multirow[t]{4}{*}{ Morocco Overall } & Constant & 0.00114 & $0.049 /-0.083$ & -0.00109 & 0.02073 & -0.0086 & 0.01141 & -0.00399 & -0.00305 & 24 \\
\hline & Market Beta & 1.07974 & $1.260 / 0.725$ & 1.25669 & 1.32139 & 1.03298 & 1.06888 & 0.94118 & 0.84827 & \\
\hline & Size Beta & -0.16781 & $0.294 /-0.452$ & -0.11563 & -0.3746 & 0.01909 & -0.09827 & -0.05564 & -0.09753 & \\
\hline & Illiquidity Beta & 0.12044 & $0.370 /-0.049$ & 0.11986 & 0.13482 & 0.06735 & 0.19207 & 0.07388 & 0.09284 & \\
\hline Tunisia Basic & Constant & -0.00407 & $0.119 /-0.111$ & 0.00717 & -0.02792 & -0.03042 & 0.01808 & -0.00305 & -0.01191 & 25 \\
\hline \multirow[t]{3}{*}{ Materials } & Market Beta & 0.56726 & $1.186 / 0.067$ & 0.93729 & 0.86246 & 0.62597 & 0.40140 & 0.19561 & 0.17388 & \\
\hline & Size Beta & -- -- & -- -- & -- -- & -- -- & -- -- & -- -- & --- & -- -- & \\
\hline & Illiquidity Beta & 0.10231 & $0.183 / 0.021$ & 0.14809 & 0.12565 & 0.05526 & 0.0416 & 0.04347 & 0.04199 & \\
\hline
\end{tabular}




\begin{tabular}{|c|c|c|c|c|c|c|c|c|c|c|}
\hline Country & & $\begin{array}{l}\text { Overall } \\
\text { Mean }\end{array}$ & Overall High/ low & 2003 & 2004 & 2005 & 2006 & 2007 & 2008 & $\begin{array}{c}\text { Convergence } \\
\text { (Iterations) }\end{array}$ \\
\hline Tunisia & Constant & -- -- & ---- & ---- & ---- & -- -- & ---- & ---- & ---- & No \\
\hline \multirow[t]{3}{*}{ Communications } & Market Beta & ---- & -- -- & -- -- & -- -- & -- -- & -- -- & -- -- & -- -- & Convergence \\
\hline & Size Beta & -- -- & -- -- & -- -- & -- -- & -- -- & -- -- & -- -- & ---- & \\
\hline & Illiquidity Beta & -- -- & -- -- & -- -- & ---- & ---- & -- -- & ---- & -- -- & \\
\hline Tunisia Consumer & Constant & -0.00068 & $0.064 /-0.066$ & -0.00973 & 0.01081 & -0.01197 & 0.00023 & 0.02963 & 0.01778 & 26 \\
\hline \multirow{3}{*}{ Cyclicals } & Market Beta & 0.05872 & $3.766 /-1.362$ & -0.03091 & 1.05911 & 0.10484 & 0.59723 & -0.09470 & 0.49296 & \\
\hline & Size Beta & -0.17778 & $0.558 /-2.531$ & 0.02752 & -0.11765 & -0.16006 & -0.57123 & 0.14197 & -0.28656 & \\
\hline & Illiquidity Beta & 0.01474 & $0.052 /-0.048$ & -0.01878 & -0.01636 & 0.00907 & 0.02987 & 0.04913 & 0.04640 & \\
\hline Tunisia Consumer & Constant & 0.00012 & $0.053 /-0.125$ & 0.05587 & -0.01337 & 0.00335 & 0.01736 & -0.00516 & 0.01109 & 13 \\
\hline \multirow{3}{*}{ Non Cyclical } & Market Beta & -0.14907 & $6.495 /-1.381$ & -0.97612 & 1.42912 & 0.96897 & -0.26281 & 0.34314 & 0.51518 & \\
\hline & Size Beta & -- -- & -- -- & -- -- & -- -- & -- -- & -- -- & -- -- & -- -- & \\
\hline & Illiquidity Beta & -0.02055 & $0.072 / 0.022$ & 0.02285 & 0.05622 & 0.03686 & 0.03426 & 0.04120 & 0.04407 & \\
\hline \multirow[t]{4}{*}{ Tunisia Financials } & Constant & 0.00934 & $0.174 /-0.083$ & -0.0093 & 0.00849 & 0.04825 & 0.00943 & -0.01442 & 0.04632 & 17 \\
\hline & Market Beta & 0.25499 & $4.842 /-3.431$ & 0.74763 & 0.23159 & -1.21317 & 0.66173 & 1.88442 & 0.61040 & \\
\hline & Size Beta & -0.00707 & $0.009 /-0.042$ & -0.01526 & -0.01272 & -0.02992 & -0.02818 & -0.00962 & $9.48 \mathrm{E}-05$ & \\
\hline & Illiquidity Beta & 0.07574 & $0.758 /-0.461$ & 0.05391 & 0.08017 & -0.22273 & 0.23735 & 0.45822 & 0.17047 & \\
\hline Tunisia & Constant & -0.03429 & $0.371 /-0.647$ & 0.01128 & 0.02014 & 0.04232 & -0.07909 & -0.27141 & 0.02548 & 14 \\
\hline \multirow[t]{3}{*}{ Industrials } & Market Beta & 0.96099 & $13.484 /-2.631$ & -0.34651 & 0.32280 & -1.19162 & 5.83043 & 3.98859 & 0.89858 & \\
\hline & Size Beta & ---- & ---- & -- -- & -- -- & -- -- & -- -- & -- -- & ---- & \\
\hline & Illiquidity Beta & 0.04740 & $1.029 /-0.143$ & -0.08367 & 0.02431 & -0.05948 & 0.49041 & 0.34993 & 0.12411 & \\
\hline \multirow[t]{4}{*}{ Tunisia Overall } & Constant & 0.00034 & $0.130 /-0.097$ & -0.00257 & 0.00585 & 0.02591 & 0.01457 & -0.04483 & 0.02485 & 27 \\
\hline & Market Beta & 0.34871 & $2.946 /-1.584$ & 0.70856 & 0.50385 & -0.58715 & 1.32084 & 1.45901 & 0.37506 & \\
\hline & Size Beta & -- -- & -- -- & -- -- & -- -- & -- -- & -- -- & -- -- & -- -- & \\
\hline & Illiquidity Beta & 0.06631 & $0.483 /-0.226$ & 0.08645 & 0.06689 & -0.1122 & 0.24351 & 0.29797 & 0.08067 & \\
\hline Egypt & Constant & -0.00751 & $0.114 /-0.126$ & -0.00329 & 0.01699 & -0.02231 & -0.05325 & -0.02608 & -0.00274 & 14 \\
\hline \multirow[t]{3}{*}{ Materials } & Market Beta & 1.67954 & $1.874 / 1.255$ & 1.65768 & 1.67709 & 1.50962 & 1.55211 & 1.37385 & 1.41394 & \\
\hline & Size Beta & 0.09148 & $0.179 /-0.059$ & 0.09836 & 0.02045 & 0.09935 & 0.10327 & 0.00535 & -0.00127 & \\
\hline & Illiquidity Beta & -- -- & ---- & -- -- & ---- & ---- & -- -- & ---- & -- -- & \\
\hline
\end{tabular}




\begin{tabular}{|c|c|c|c|c|c|c|c|c|c|c|}
\hline Country & & $\begin{array}{l}\text { Overall } \\
\text { Mean }\end{array}$ & Overall High/ low & 2003 & 2004 & 2005 & 2006 & 2007 & 2008 & $\begin{array}{c}\text { Convergence } \\
\text { (Iterations) }\end{array}$ \\
\hline Egypt & Constant & 0.00336 & $0.229 /-0.103$ & -0.01188 & 0.03429 & 0.02536 & 0.00415 & -0.02404 & 0.05480 & 39 \\
\hline \multirow[t]{3}{*}{ Communications } & Market Beta & 0.35354 & $0.903 /-0.636$ & 0.63016 & -0.05833 & 0.01201 & 0.42906 & -0.02319 & 0.31510 & \\
\hline & Size Beta & -0.25109 & $0.310 /-0.603$ & -0.43839 & -0.41365 & -0.49187 & -0.48228 & 0.21106 & 0.03082 & \\
\hline & Illiquidity Beta & -0.24798 & $-0.048 /-0.447$ & -0.31427 & -0.49147 & -0.3275 & -0.25037 & -0.13114 & -0.14795 & \\
\hline Egypt Consumer & Constant & -0.00620 & $0.184 /-0.102$ & -0.01618 & $3.01 \mathrm{E}-05$ & -0.03258 & -0.02133 & 0.00663 & 0.02019 & 19 \\
\hline \multirow[t]{3}{*}{ Cyclicals } & Market Beta & 1.54193 & $3.573 / 0.463$ & 1.67543 & 2.64545 & 2.08683 & 1.16519 & 0.88050 & 1.25817 & \\
\hline & Size Beta & 0.04897 & $0.324 /-0.269$ & 0.23061 & 0.16131 & -0.08384 & -0.08788 & -0.08557 & -0.11062 & \\
\hline & Illiquidity Beta & -0.07495 & $0.643 /-0.828$ & -0.12781 & 0.28112 & -0.03413 & -0.10102 & -0.35816 & -0.11854 & \\
\hline Egypt Consumer & Constant & -0.00296 & $0.052 /-0.045$ & -0.01641 & -0.01286 & -0.0045 & -0.02689 & 0.00403 & 0.02886 & 22 \\
\hline \multirow[t]{3}{*}{ Non-Cyclicals } & Market Beta & 1.00713 & $2.533 / 0.180$ & 1.39134 & 0.97337 & 0.74928 & 0.83041 & 0.76549 & 1.84416 & \\
\hline & Size Beta & 0.06593 & $0.183 /-0.107$ & 0.12150 & -0.02268 & -0.05603 & 0.06047 & 0.07228 & 0.15360 & \\
\hline & Illiquidity Beta & -0.02533 & $0.519 /-0.300$ & 0.03838 & 0.00412 & -0.05159 & -0.07326 & -0.06596 & 0.10747 & \\
\hline \multirow[t]{4}{*}{ Egypt Financials } & Constant & 0.00151 & $0.079 /-0.058$ & -0.00531 & -0.00239 & 0.00168 & 0.02048 & 0.02937 & -0.03609 & 26 \\
\hline & Market Beta & 1.03566 & $2.295 / 0.049$ & 0.46677 & 0.80768 & 1.27950 & 1.19298 & 0.97513 & 1.09214 & \\
\hline & Size Beta & 0.10975 & $0.179 / 0.018$ & 0.17766 & 0.16411 & 0.10833 & 0.06039 & 0.03865 & 0.03098 & \\
\hline & Illiquidity Beta & -0.10317 & $0.047 /-0.231$ & -0.08007 & -0.15202 & -0.09687 & -0.12044 & -0.15515 & -0.05204 & \\
\hline \multirow[t]{4}{*}{ Egypt Industrial } & Constant & -0.00501 & $0.065 /-0.061$ & -0.01221 & 0.02335 & 0.01708 & 0.01093 & -0.02389 & -0.03071 & 52 \\
\hline & Market Beta & 1.27868 & $4.660 /-0.278$ & 1.67094 & 1.14408 & 0.86259 & 0.67987 & 2.11924 & 1.08545 & \\
\hline & Size Beta & 0.12612 & $1.072 /-0.941$ & 0.04112 & 0.27524 & 0.57803 & 0.04460 & -0.02246 & -0.23084 & \\
\hline & Illiquidity Beta & -0.09257 & $-0.032 /-0.166$ & -0.07236 & -0.07593 & -0.09256 & -0.12412 & -0.13746 & -0.14974 & \\
\hline \multirow[t]{4}{*}{ Egypt CASE 70} & Constant & -0.00398 & $0.056 /-0.056$ & -0.01193 & 0.00182 & -0.00688 & 0.00509 & -0.00695 & -0.01712 & 20 \\
\hline & Market Beta & 1.25725 & $1.459 / 0.997$ & 1.30538 & 1.15429 & 1.03756 & 1.09232 & 1.21251 & 1.31487 & \\
\hline & Size Beta & 0.1266 & $0.655 /-0.368$ & 0.06433 & 0.13049 & 0.44757 & 0.11773 & -0.10089 & 0.12558 & \\
\hline & Illiquidity Beta & -0.08872 & $0.059 /-0.345$ & -0.07118 & -0.02432 & -0.0436 & -0.07485 & -0.23214 & -0.15262 & \\
\hline CASE & Constant & 0.00084 & $0.046 /-0.034$ & -0.00592 & 0.00353 & -0.00665 & -0.00076 & 0.01466 & -0.00198 & 18 \\
\hline \multirow[t]{3}{*}{ Overall } & Market Beta & 1.16478 & $1.451 / 0.465$ & 1.06640 & 1.26235 & 1.27300 & 0.90362 & 0.98643 & 1.24821 & \\
\hline & Size Beta & 0.09175 & $0.129 / 0.021$ & 0.13950 & 0.11048 & 0.11281 & 0.06484 & 0.03339 & 0.03299 & \\
\hline & Illiquidity Beta & -0.07264 & $-0.031 /-0.179$ & -0.06479 & -0.05322 & -0.05255 & -0.10474 & -0.1334 & -0.06211 & \\
\hline
\end{tabular}

Notes: Means calculated both annually and across entire sample period. High/ Low values given for the entire sample period 
Table 11. Cost of Equity estimates derived from multi-factor regression (\%)

\begin{tabular}{|c|c|c|c|}
\hline & $\begin{array}{l}\text { Cost of Equity } \\
\text { Size-Liquidity } \\
\text { CAPM (Individual } \\
\text { Market universe) }\end{array}$ & $\begin{array}{l}\text { Size-Liquidity CAPM } \\
\text { (North African Market } \\
\text { universe) }\end{array}$ & $\begin{array}{l}\text { Size-Liquidity } \\
\text { Time-varying } \\
\text { coefficient }\end{array}$ \\
\hline \multicolumn{4}{|l|}{ Algeria } \\
\hline Consumer Cyclicals & -- -- & $9.25 \%$ & $13.99 \%$ \\
\hline Consumer Non-Cyclicals & -- -- & $12.55 \%$ & $10.88 \%$ \\
\hline Overall & -- -- & $10.68 \%$ & $6.57 \%$ \\
\hline \multicolumn{4}{|l|}{ Morocco } \\
\hline Basic Materials & $13.54 \%$ & $13.73 \%$ & $25.86 \%$ \\
\hline Consumer Cyclicals & $14.68 \%$ & $15.63 \%$ & $26.74 \%$ \\
\hline Consumer Non-Cyclicals & $10.98 \%$ & $10.85 \%$ & $9.50 \%$ \\
\hline Diversified & $12.14 \%$ & $15.41 \%$ & $17.35 \%$ \\
\hline Financials & $15.26 \%$ & $18.10 \%$ & $33.08 \%$ \\
\hline Industrial & $13.24 \%$ & $16.08 \%$ & $21.46 \%$ \\
\hline Marche Principal & $13.45 \%$ & $14.39 \%$ & $25.88 \%$ \\
\hline Marche Developpement & $14.97 \%$ & $14.95 \%$ & $21.83 \%$ \\
\hline Marche Croissance & $15.49 \%$ & $11.78 \%$ & $25.62 \%$ \\
\hline Overall & ---- & $15.04 \%$ & $27.35 \%$ \\
\hline \multicolumn{4}{|l|}{ Tunisia } \\
\hline Basic Materials & $4.63 \%$ & $7.97 \%$ & $20.06 \%$ \\
\hline Communications & $14.06 \%$ & $11.93 \%$ & -- -- \\
\hline Consumer Cyclicals & $32.60 \%$ & $19.68 \%$ & $5.95 \%$ \\
\hline Consumer Non-Cyclicals & $17.08 \%$ & $10.03 \%$ & $6.05 \%$ \\
\hline Financials & $23.47 \%$ & $18.49 \%$ & $10.49 \%$ \\
\hline Industrial & $55.80 \%$ & $29.26 \%$ & $28.08 \%$ \\
\hline Overall & -- -- & $17.34 \%$ & $12.89 \%$ \\
\hline \multicolumn{4}{|l|}{ Egypt } \\
\hline Basic Materials & $32.55 \%$ & $30.87 \%$ & $51.40 \%$ \\
\hline Communications & $21.36 \%$ & $23.76 \%$ & $20.94 \%$ \\
\hline Consumer Cyclicals & $29.91 \%$ & $33.79 \%$ & $48.48 \%$ \\
\hline Consumer Non-Cyclicals & $28.44 \%$ & $28.91 \%$ & $32.07 \%$ \\
\hline Diversified & $31.71 \%$ & $43.86 \%$ & $51.73 \%$ \\
\hline Financials & $32.58 \%$ & $33.28 \%$ & $35.33 \%$ \\
\hline Industrial & $29.12 \%$ & $36.62 \%$ & $42.39 \%$ \\
\hline CASE 70 & $32.52 \%$ & $32.41 \%$ & $41.69 \%$ \\
\hline CASE Overall & ---- & $32.03 \%$ & $38.11 \%$ \\
\hline
\end{tabular}

Notes: (1) Annualized cost of equity estimates generated at 12/2008 from the total risk premium

(2) The UK 3 Month Gilt/ Treasury rate is used in each case for risk free rate 
Figure 1. Time varying liquidity betas for Morocco Overall

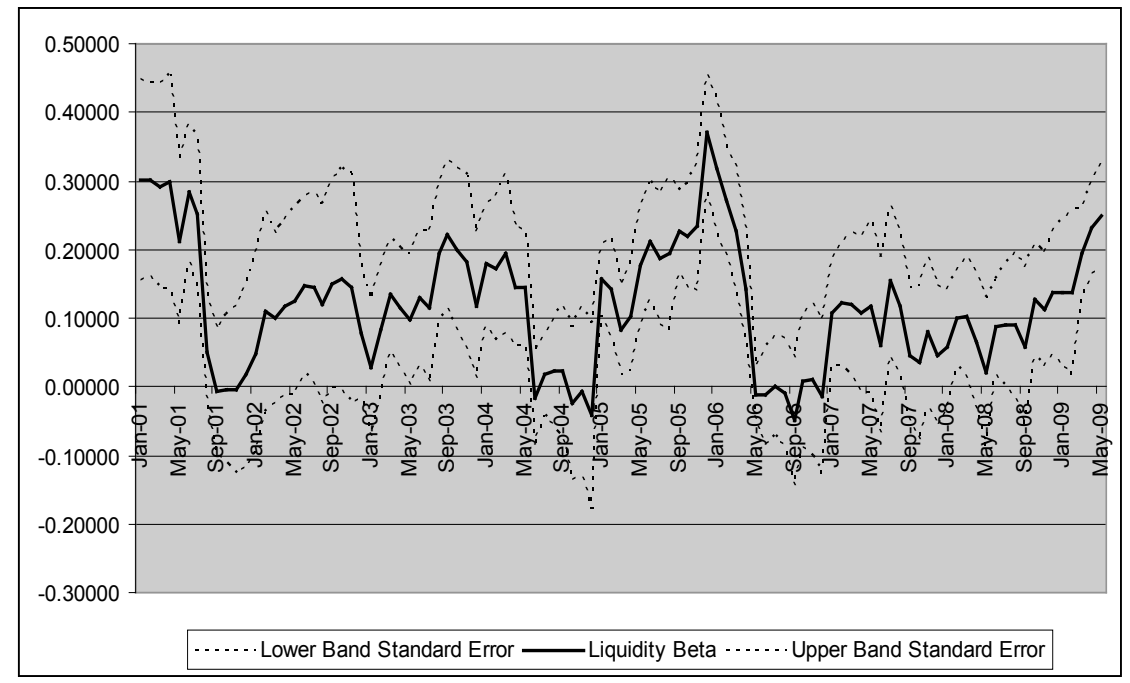

Figure 3. Time varying liquidity betas for Morocco Marché développement

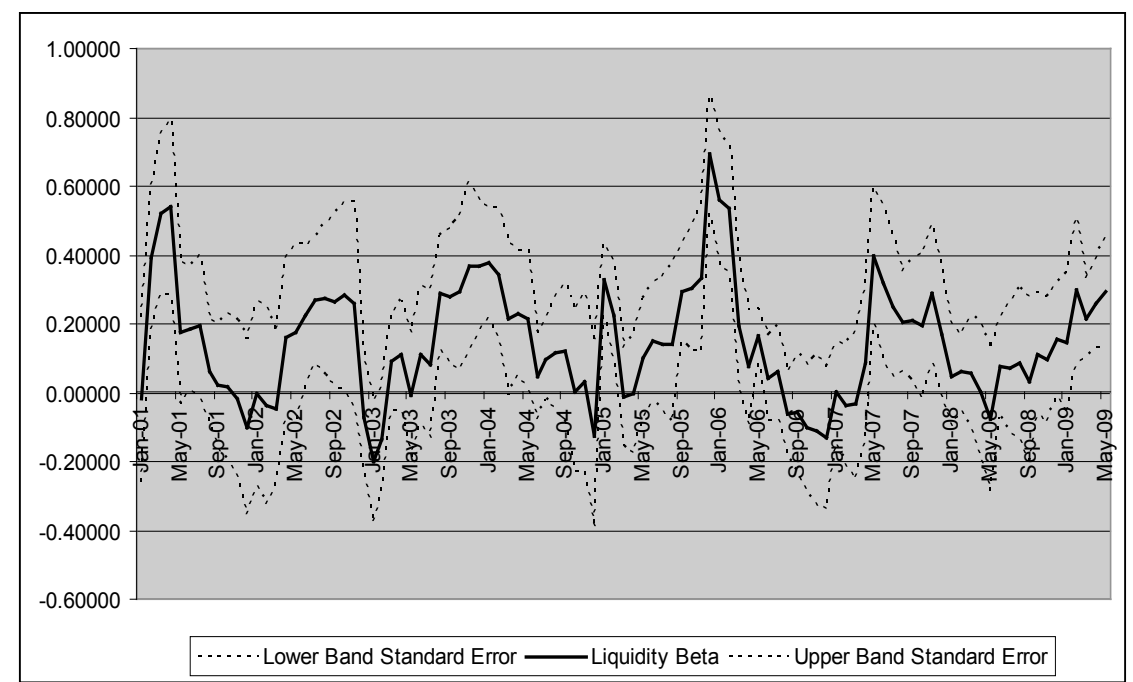

Figure 2. Time varying liquidity betas for Morocco Marché principal

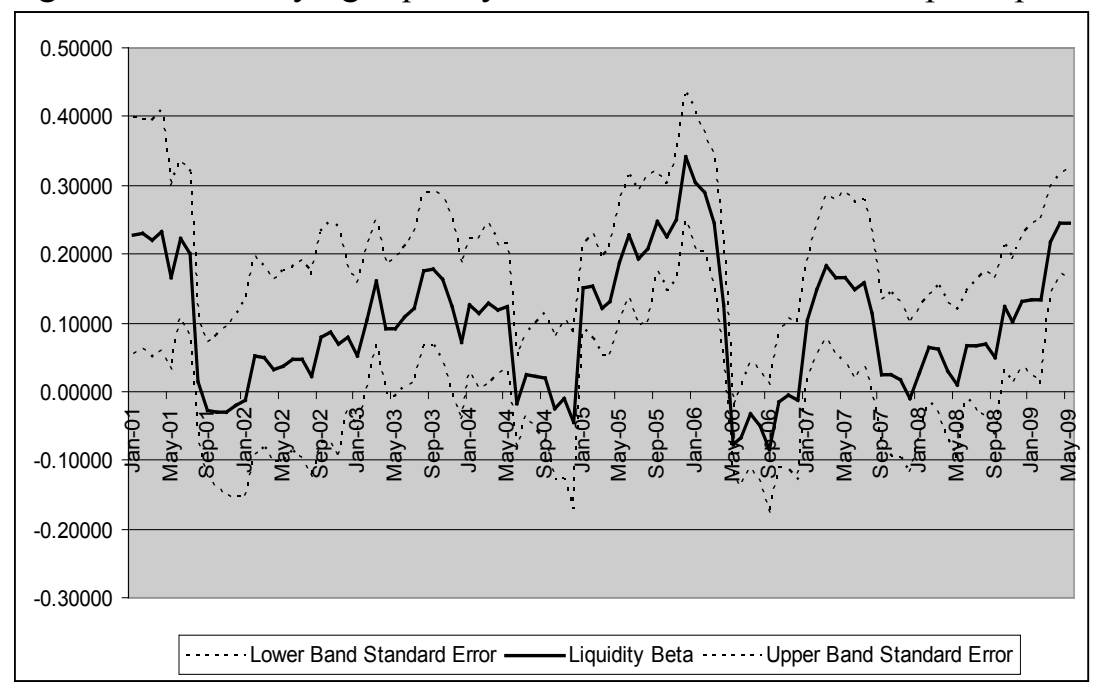

Figure 4. Time varying liquidity betas for Morocco Marché croissance

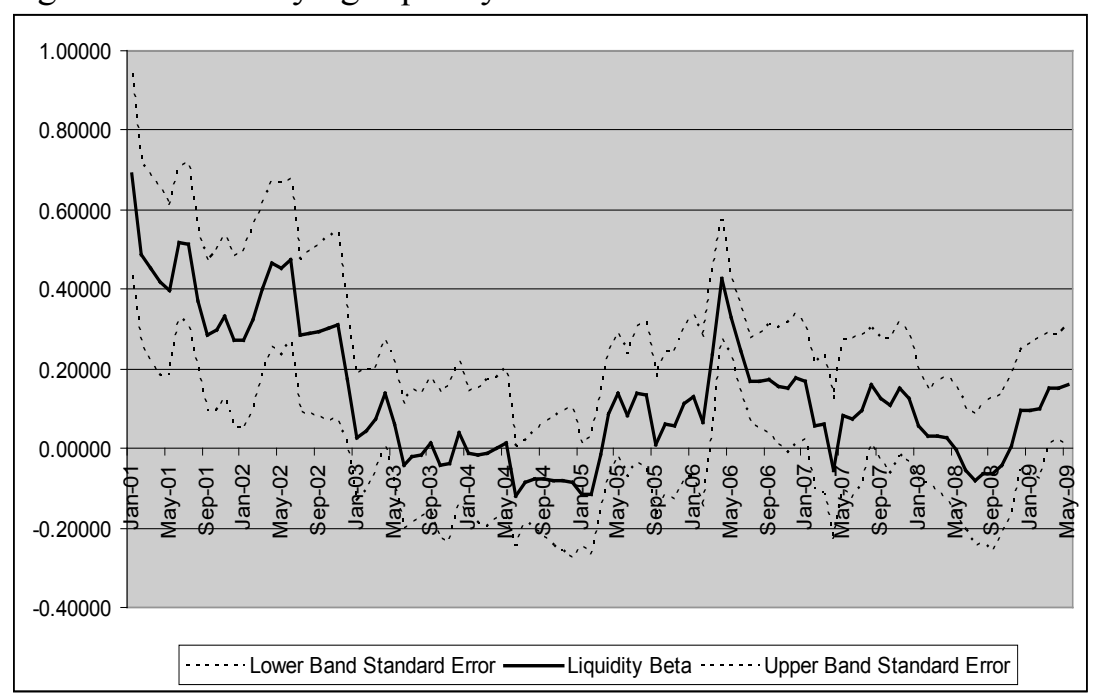


Figure 5. Time varying liquidity betas for Tunisia

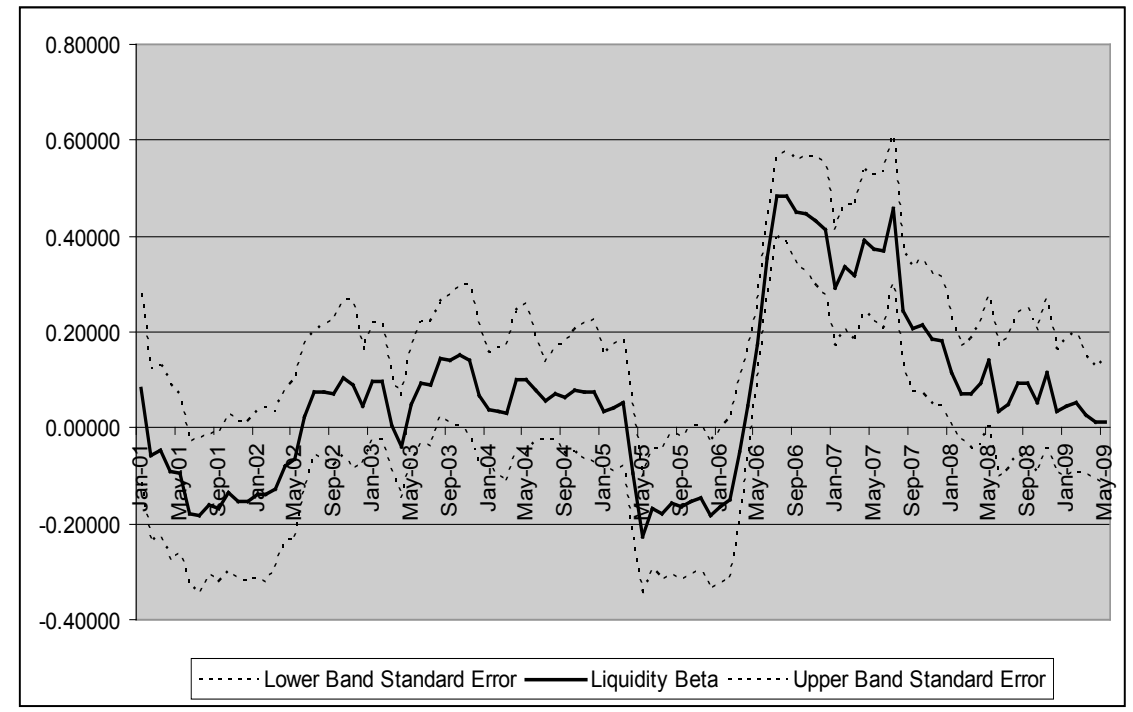

Figure 7. Time varying liquidity betas for Egypt CASE70

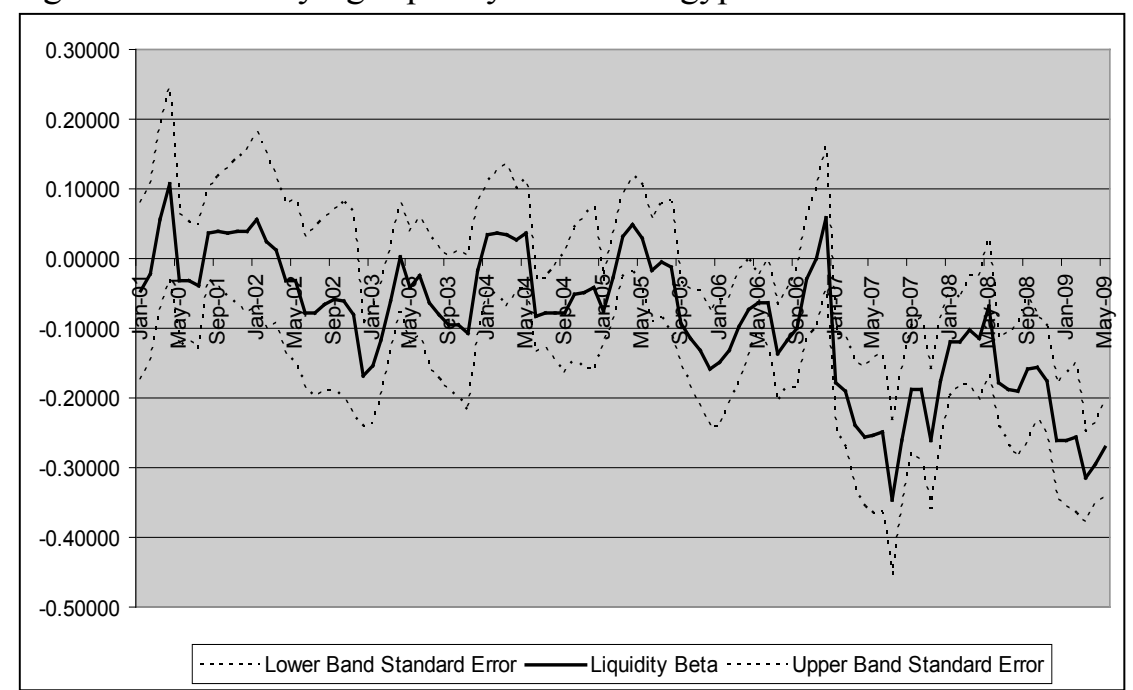

Figure 6. Time varying liquidity betas for Egypt Overall

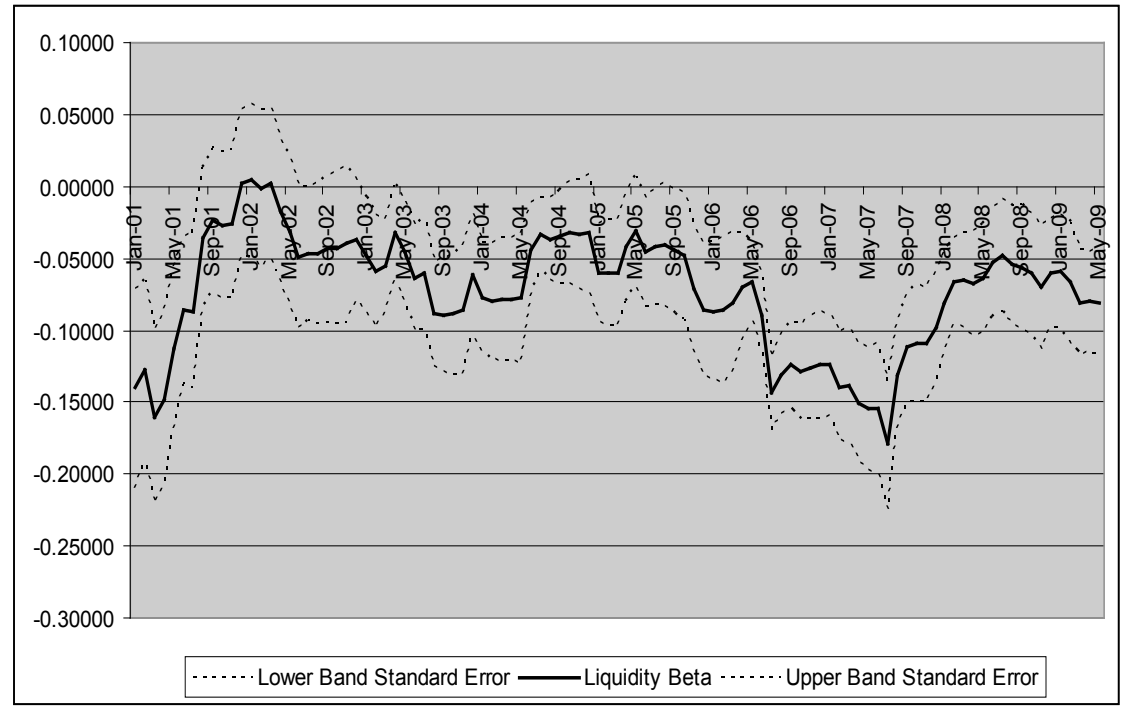

